\title{
The Communication and Risk Management of Volcanic Ballistic Hazards
}

\author{
R.H. Fitzgerald, B.M. Kennedy, T.M. Wilson, G.S. Leonard, \\ $\mathrm{K}$. Tsunematsu and $\mathrm{H}$. Keys
}

\begin{abstract}
Tourists, hikers, mountaineers, locals and volcanologists frequently visit and reside on and around active volcanoes, where ballistic projectiles are a lethal hazard. The projectiles of lava or solid rock, ranging from a few centimetres to several metres in diameter, are erupted with high kinetic, and sometimes thermal, energy. Impacts from projectiles are amongst the most frequent causes of fatal volcanic incidents and the cause of hundreds of thousands of dollars of damage to buildings, infrastructure and property worldwide. Despite this, the assessment of risk and communication of ballistic hazard has received surprisingly little study. Here, we review the research to date on ballistic distributions, impacts, hazard and risk assessments and maps, and methods of communicating and managing ballistic risk including how these change with a changing risk environment. The review suggests future improvements to the communication and management of ballistic hazard.
\end{abstract}

\section{Keywords}

Volcanic ballistics - Volcanic hazard - Volcanic risk • Risk communication - Risk management

R.H. Fitzgerald $(\bowtie) \cdot$ B.M. Kennedy · T.M. Wilson Department of Geological Sciences, University of Canterbury, Private Bag 4800, Christchurch 8140, New Zealand

e-mail: rebecca.fitzgerald@pg.canterbury.ac.nz

G.S. Leonard

GNS Science, PO Box 30368, Lower Hutt 5040,

New Zealand

\section{K. Tsunematsu}

Mt. Fuji Research Institute (MFRI), 5597-1

Kenmarubi Kamiyoshida Fujiyoshida-Shi,

Yamanashi 403-0005, Japan

H. Keys

Department of Conservation, PO Box 528, Taupo

3351, New Zealand 


\section{Introduction}

Ballistic projectiles are one potentially lethal and damaging hazard produced in volcanic eruptions. Ballistics are fragments of lava (bombs) or rock (blocks) ejected in explosive eruptions (Fig. 1a, b). Projectiles range from a few centimetres to tens of metres in diameter and separate from the eruptive column to follow nearly parabolic trajectories (Wilson 1972; Fagents and Wilson 1993; Bower and Woods 1996). Their exit velocities can reach hundreds of metres per second and land up to $\sim 10 \mathrm{~km}$ from the vent, although typically within five kilometres (Blong 1984; Alatorre-Ibargüengoitia et al. 2012). Ballistics are associated with all forms of explosive eruptions but are considered major hazards of hydrothermal, phreatic, phreatomagmatic, Strombolian and Vulcanian eruptions, especially those which have little to no precursory signals of volcanic unrest. Managing ballistic hazard and risk on active volcanoes, particularly those permanently occupied or regularly visited, presents considerable challenges: it requires good information and specialist communication strategies around risk mitigation, preparedness, response, and recovery dependent on the state of the volcano, e.g. pre-, during- and post-eruption. In this chapter, we present an overview of volcanic ballistic hazards and impacts and the communication strategies used to manage risk on active volcanoes.

\section{Ballistic Hazard and Risk Management}

Ballistic projectiles are a risk to life on active volcanoes and can cause substantial damage to exposed infrastructure and the environment due to their high kinetic energy, mass, and often high temperatures (Blong 1984). Volcanic ballistic projectiles are amongst the most frequent causes of fatal incidents on volcanoes, with at least 76 recorded deaths at six volcanoes (Galeras, Yasur, Popocatepetl, Pacaya, Raoul Island and Ontake) since 1993 (Baxter and Gresham 1997; Cole et al. 2006; Alatorre-Ibargüengoitia et al. 2012;
Wardman et al. 2012; Tsunematsu et al. 2016). Many more people have been injured as a result of ballistic impacts, frequently suffering from blunt force trauma (broken bones), lacerations, burns, abrasions and bruising (Blong 1984; Baxter and Gresham 1997). Additionally, damage to buildings (Fig. 1c, e), infrastructure, property and the surrounding environment (Fig. 1d) are also common occurrences from ballistics during explosive eruptions. The high kinetic and thermal energy of ballistics can puncture, dent, melt, burn and knock down structures and their associated systems, such as power supply and telecommunication masts; crater roads; and crush and potentially ignite crops (Booth 1979; Calvari et al. 2006; Pistolesi et al. 2008; Alatorre-Ibargüengoitia et al. 2012; Wardman et al. 2012; Maeno et al. 2013; Fitzgerald et al. 2014; Jenkins et al. 2014). Blong (1981), Pomonis et al. (1999) and Jenkins et al. (2014) estimate a ballistic only needs 400-1000 J of kinetic energy to penetrate a metal sheet roof, far less than the estimated kinetic energy of ballistics $\left(\sim 10^{6} \mathrm{~J}\right)$ from VEI 2-4 eruptions (Alatorre-Ibargüengoitia et al. 2012).

The distribution (distance from vent, direction, area and density) of ejected ballistics is controlled by the explosivity, type, size and direction of explosive eruptions, and usually creates spatially variable deposits (Gurioli et al. 2013; Breard et al. 2014; Fitzgerald et al. 2014). Generally, the distance travelled and the total area impacted by ballistics increases with increasing explosivity, i.e. particles generally travel further and cover a greater area in Vulcanian eruptions (Nairn and Self 1978; Alatorre-Ibargüengoitia et al. 2012; Maeno et al. 2013) compared with Strombolian eruptions (Harris et al. 2012; Gurioli et al. 2013; Turtle et al. 2016). However, eruptions can be directed, ejecting ballistics at low angles and at distances greater than those from more vertically directed eruptions (Fitzgerald et al. 2014; Tsunematsu et al. 2016). The directionality of these blasts is often unpredictable, and can be influenced by external factors such as landslides (Christiansen 1980; Breard et al. 2014), making it difficult to deterministically forecast future ballistic 

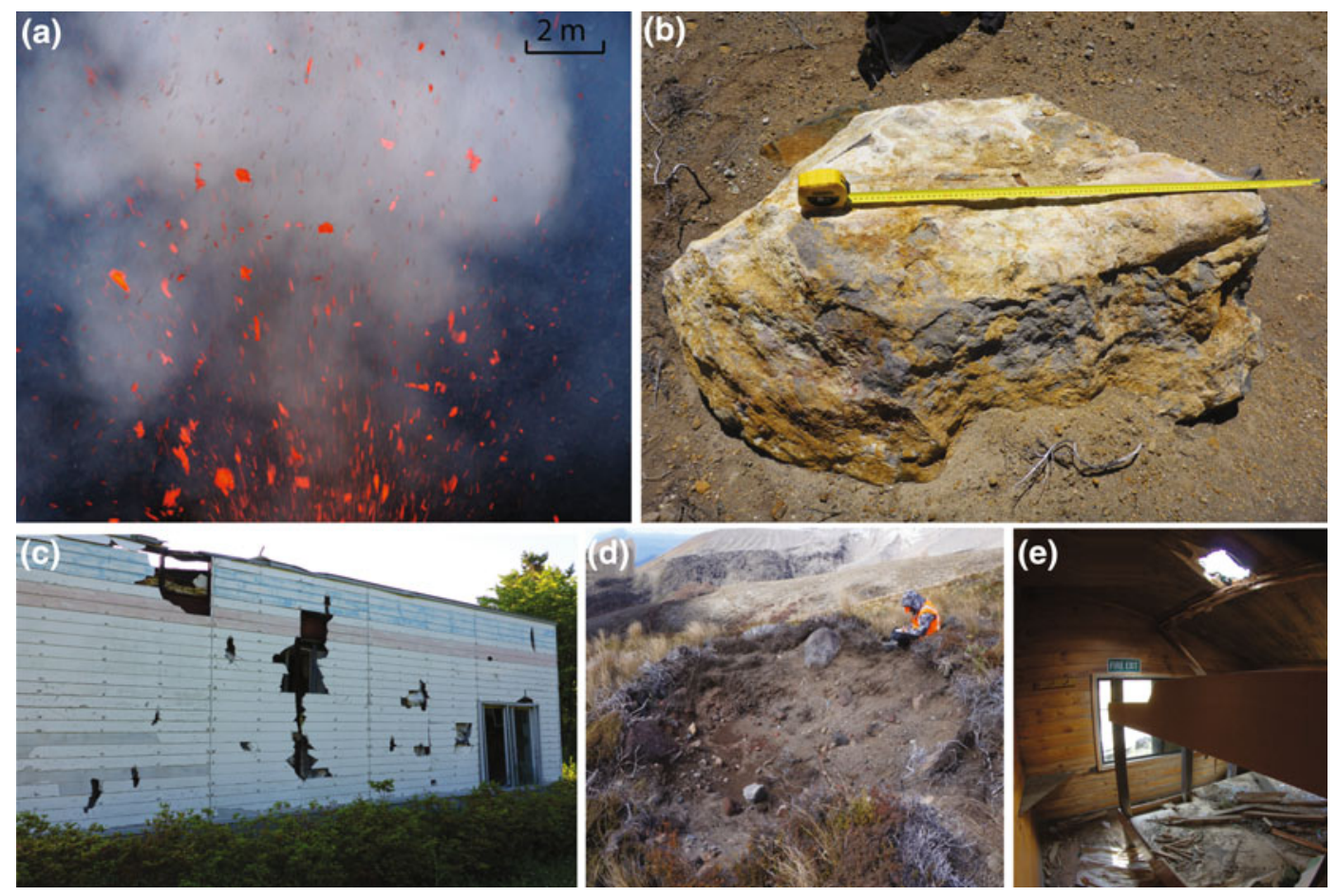

Fig. 1 Types of ballistic particles and their impacts: a Ballistic bombs from Yasur Volcano, Vanuatu (Photo credit Ben Kennedy), b Ballistic blocks (1.4 m diameter block) from the August 2012 Upper Te Maari eruption, c Damage to a building from ballistics ejected in the 2000

distributions. Mapped deposits from past eruptions are often not symmetrical around the vent, reflecting this directionality (Minakami 1942; Fudali and Melson 1972; Steinberg and Lorenz 1983; Kilgour et al. 2010; Houghton et al. 2011; Gurioli et al. 2013; Fitzgerald et al. 2014), and are sometimes the result of the crater and surrounding topography (Breard et al. 2014; Tsunematsu et al. 2016). Detailed descriptions and maps of ballistic impact distributions are rare, but those published may contain some of the following data: maximum ballistic travel distances (Steinberg and Lorenz 1983; Robertson et al. 1998; Kaneko et al. 2016); the outer edges of a ballistic field (Minakami 1942; Nairn and Self 1978; Yamagishi and Feebrey 1994); and/or maximum particle (Nairn and Self 1978; Steinberg and Lorenz 1983; Robertson et al. 1998;
Mt. Usu, Japan eruption, d Damage to the environment illustrated by a $4.4 \mathrm{~m}$ wide crater from the August 2012 Upper Te Maari, Tongariro eruption, e Damage to a hiking hut from 2012 Upper Te Maari ballistics (Photo credit Nick Kennedy)

Swanson et al. 2012) or crater size (Robertson et al. 1998; Maeno et al. 2013; Kaneko et al. 2016). When isopleths of particle size are included these rarely contain individual measurements and may be severely limited by the availability of only specific mapped locations (e.g., Kilgour et al. 2010; Houghton et al. 2011). For this reason, the number of particles, sizes of particles, and spatial density per unit area is rarely reported (only four publications could be found with this level of detail-Pistolesi et al. 2008; Swanson et al. 2012; Gurioli et al. 2013; Kaneko et al. 2016). This leads to a limited understanding of the hazard and risk posed to the area.

Though work has been completed on ballistic hazard (e.g., mapping deposits, better understanding eruption dynamics and the factors that 
influence ballistic distribution, recording particle velocities, the creation and use of ballistic trajectory models, and the production of hazard maps either focussed solely on ballistics or as an aspect of a multi-hazard map), very little has been focussed on the management of ballistic risk, leaving a large knowledge gap and a need for research in this area. Risk management strategies and mitigation systems are key to protecting life and infrastructure from ballistic hazards (Leonard et al. 2008; Bertolaso et al. 2009; Bird et al. 2010; Jolly et al. 2014b). Table 1 lists some of the strategies and tools used at volcanoes around the world.

Effective communication of ballistic hazard and risk to end-users such as the public, stakeholders in the area and emergency managers underpins effective development and implementation of these risk management strategies. However, ballistic hazard and risk are not and should not be treated the same at all volcanoes. The risk environment (the hazard, the number of people and assets exposed and their associated vulnerability) will determine the strategies, tools and methods of communication, and their relative importance, utilised in the overall risk management strategy. The volcano tourism industry is also growing (Sigurdsson and Lopes-Gautier 1999; Erfurt-Cooper 2011), increasing the number of people exposed to ballistic hazard in proximal areas. In addition, population growth in many volcanic regions means increasing numbers of people are settling closer to and on volcanoes (Small and Naumann 2001; Ewart and Harpel 2004). This creates an increasing demand for ballistic hazard and risk assessments coupled with effective communication strategies to manage ballistic risk at volcanoes. Ballistics are not a hazard in isolation. Their management needs to be integrated with that of other volcanic hazards (especially pyroclastic density currents in terms of near-vent life safety, but also landslides, lahars, lava flows, and volcanic gas emissions/areas of hot ground), and other life safety issues such as severe weather and mountain safety.

\section{Assessments of Ballistic Hazard and Risk}

Successful management of the risk from ballistic hazards typically requires first assessing the level of risk. This may range from the simple recognition that ballistics may endanger people or their activities on a volcano through to a sophisticated quantitative hazard or risk assessment (e.g. Alatorre-Ibargüengoitia et al. 2012; Jolly et al. 2014b). Ballistic hazard assessments determine the likelihood of ballistic-producing eruptions and the areas that may be impacted (Thouret et al. 2000; Alatorre-Ibargüengoitia et al. 2012). Risk assessments estimate the likelihood of consequences (i.e. death, injury, damage) from exposure to ballistics, typically with an associated probability of occurrence (Blong 1996). Once the level of risk has been assessed it can be used as the robust basis for risk management strategies, such as exclusion zones, hazard/risk maps and signs, and land-use planning. Ideal assessments involve a number of steps including: (1) a review of the eruption history of the volcano to determine past eruption frequencies and magnitudes, thus informing future eruption probabilities; (2) field mapping, remote sensing and/or review of past reports and literature to determine the nature and extent of past ballistic distributions; (3) utilising ballistic trajectory models to explore possible future distributions and areas of hazard; (4) identifying exposed assets in the area such as humans (visitors and inhabitants) and infrastructure; and (5) estimating their vulnerability to the hazard i.e. likelihood of fatality or damage (Nadim 2013). Assessments are ideally probabilistic, providing spatially varying probabilities of occurrence and damage from a range of scenarios varying in frequency and magnitude, and accounting for model and input parameter uncertainty. They should be constantly refined and improved as new information becomes available.

A hazard map is a primary tool used to present hazard and risk information (Sparks et al. 2013). Zonation is generally used as a means to 
Table 1 Risk management and communication strategies with selected example volcanoes where they have been employed

\begin{tabular}{|c|c|c|c|}
\hline $\begin{array}{l}\text { Risk } \\
\text { management } \\
\text { strategy }\end{array}$ & Description & $\begin{array}{l}\text { Selected examples } \\
\text { of volcanoes } \\
\text { where strategy } \\
\text { has been used }\end{array}$ & References \\
\hline $\begin{array}{l}\text { Hazard and } \\
\text { risk } \\
\text { assessments }\end{array}$ & $\begin{array}{l}\text { Hazard assessments determine the } \\
\text { likelihoods of hazard producing } \\
\text { events and the areas that may be } \\
\text { impacted. These can be expanded } \\
\text { to risk assessments to determine } \\
\text { the likelihood of consequences to } \\
\text { people and/or other societal assets. } \\
\text { They underpin and inform other } \\
\text { risk management strategies }\end{array}$ & $\begin{array}{l}\text { Tongariro } \\
\text { Mt. Fuji } \\
\text { Popocatepetl } \\
\text { El Chichon }\end{array}$ & $\begin{array}{l}\text { Mount Fuji Disaster Prevention } \\
\text { Council (2004), } \\
\text { Alatorre-Ibargüengoitia et al. } \\
\text { (2012), Jolly et al. (2014b), } \\
\text { Alatorre-Ibargüengoitia et al. } \\
\text { (2016) }\end{array}$ \\
\hline $\begin{array}{l}\text { Hazard and } \\
\text { risk maps }\end{array}$ & $\begin{array}{l}\text { Identify zones of relative hazard } \\
\text { and/or risk, typically in a two } \\
\text { dimensional representation }\end{array}$ & $\begin{array}{l}\text { Popocatepetl } \\
\text { Mt. Fuji }\end{array}$ & $\begin{array}{l}\text { Mount Fuji Disaster Prevention } \\
\text { Council (2004), } \\
\text { Alatorre-Ibargüengoitia et al. } \\
(2012)\end{array}$ \\
\hline $\begin{array}{l}\text { Volcano } \\
\text { monitoring and } \\
\text { research }\end{array}$ & $\begin{array}{l}\text { Systems deployed on and around a } \\
\text { volcano to monitor volcanic } \\
\text { activity, and indicate when the } \\
\text { volcano is in unrest or eruption. } \\
\text { Research is also conducted on the } \\
\text { eruptive behaviour (e.g. magnitude } \\
\text { and style) and eruption frequency } \\
\text { of a volcano }\end{array}$ & $\begin{array}{l}\text { Mt. Etna } \\
\text { Tongariro } \\
\text { Sakurajima } \\
\text { Mt. Ontake }\end{array}$ & $\begin{array}{l}\text { https://www.geonet.org.nz/ } \\
\text { volcano/info/tongariro; http:// } \\
\text { www.ct.ingv.it/en/mappa-stazioni. } \\
\text { html; JMA }(2013 a, b)\end{array}$ \\
\hline $\begin{array}{l}\text { Real-time } \\
\text { warning } \\
\text { systems }\end{array}$ & $\begin{array}{l}\text { To monitor and detect a hazardous } \\
\text { event (e.g. eruption) and } \\
\text { communicate a warning to those } \\
\text { potentially exposed. }\end{array}$ & Ruapehu & $\begin{array}{l}\text { Leonard et al. (2008), Keys and } \\
\text { Green (2010) }\end{array}$ \\
\hline $\begin{array}{l}\text { Volcanic alert } \\
\text { levels, } \\
\text { bulletins and } \\
\text { media } \\
\text { advisories }\end{array}$ & $\begin{array}{l}\text { Formal communications from a } \\
\text { volcano observatory which } \\
\text { communicate changes in volcano } \\
\text { behaviour, notify emergency } \\
\text { managers and the population of an } \\
\text { eruption and advise on mitigation. }\end{array}$ & $\begin{array}{l}\text { Yasur } \\
\text { Tongariro }\end{array}$ & $\begin{array}{l}\text { https://www.geonet.org.nz/ } \\
\text { volcano/info/tongariro; http:// } \\
\text { www.geohazards.gov.vu/ }\end{array}$ \\
\hline $\begin{array}{l}\text { Emergency } \\
\text { response plans }\end{array}$ & $\begin{array}{l}\text { Plan for directing response actions } \\
\text { which aim to reduce the impacts of } \\
\text { an eruption. Plans are best } \\
\text { executed with training and } \\
\text { exercises in their use }\end{array}$ & $\begin{array}{l}\text { Ruapehu } \\
\text { Sakurajima }\end{array}$ & $\begin{array}{l}\text { Leonard et al. (2008); } \\
\text { http://www.city.tarumizu.lg.jp/ } \\
\text { kikikanri/kurashi/bosai/bosai// } \\
\text { taisaku/sakurajima.html }\end{array}$ \\
\hline $\begin{array}{l}\text { Rescue } \\
\text { services }\end{array}$ & $\begin{array}{l}\text { Deploy in emergencies to provide } \\
\text { aid to affected persons and } \\
\text { properties, e.g. Search and Rescue, } \\
\text { police, ambulance, and fire } \\
\text { services }\end{array}$ & $\begin{array}{l}\text { Ontake } \\
\text { Ruapehu }\end{array}$ & $\begin{array}{l}\text { Kilgour et al. (2010), The Japan } \\
\text { Times 27/9/2015 }\end{array}$ \\
\hline $\begin{array}{l}\text { Land use } \\
\text { planning }\end{array}$ & $\begin{array}{l}\text { Policy and regulations used to } \\
\text { minimise or exclude the } \\
\text { development of settlement and } \\
\text { construction of high-value assets in } \\
\text { hazard zones. }\end{array}$ & $\begin{array}{l}\text { Usu Volcano } \\
\text { Tongariro } \\
\text { Ruapehu }\end{array}$ & $\begin{array}{l}\text { Becker et al. (2010), Keys and } \\
\text { Green (2010) }\end{array}$ \\
\hline
\end{tabular}


Table 1 (continued)

\begin{tabular}{|c|c|c|c|}
\hline $\begin{array}{l}\text { Risk } \\
\text { management } \\
\text { strategy }\end{array}$ & Description & $\begin{array}{l}\text { Selected examples } \\
\text { of volcanoes } \\
\text { where strategy } \\
\text { has been used }\end{array}$ & References \\
\hline $\begin{array}{l}\text { Construction } \\
\text { of protective } \\
\text { shelters }\end{array}$ & $\begin{array}{l}\text { Structures designed to withstand } \\
\text { specific hazards e.g. ballistic } \\
\text { shelters in high-risk areas }\end{array}$ & $\begin{array}{l}\text { Sakurajima } \\
\text { Aso } \\
\text { Stromboli }\end{array}$ & $\begin{array}{l}\text { Bertolaso et al. (2009), } \\
\text { Erfurt-Cooper (2010) }\end{array}$ \\
\hline $\begin{array}{l}\text { Exclusion or } \\
\text { restriction } \\
\text { zones }\end{array}$ & $\begin{array}{l}\text { Area restrictions commonly used } \\
\text { temporarily during eruptions or } \\
\text { unrest. Permanent zones may be } \\
\text { required when risk is sufficiently } \\
\text { high or frequent }\end{array}$ & $\begin{array}{l}\text { Sakurajima } \\
\text { Stromboli }\end{array}$ & $\begin{array}{l}\text { Bertolaso et al. (2009), Kagoshima } \\
\text { City (2010) }\end{array}$ \\
\hline $\begin{array}{l}\text { Stakeholder } \\
\text { engagement }\end{array}$ & $\begin{array}{l}\text { Involvement of stakeholders (e.g. } \\
\text { people and organisations } \\
\text { potentially affected by an eruption) } \\
\text { in planning and activities to } \\
\text { manage the risk. This is essential } \\
\text { for effective hazard and risk } \\
\text { communication, and to establish } \\
\text { appropriate and acceptable risk } \\
\text { management strategies }\end{array}$ & $\begin{array}{l}\text { Tongariro } \\
\text { Sakurajima }\end{array}$ & $\begin{array}{l}\text { Williams and Keys (2013), Jolly } \\
\text { et al. (2014b), http://www.data. } \\
\text { jma.go.jp/svd/vois/data/fukuoka/ } \\
\text { 506_Sakurajima/506_bousai.html }\end{array}$ \\
\hline $\begin{array}{l}\text { Hazard and } \\
\text { risk education } \\
\text { resources }\end{array}$ & $\begin{array}{l}\text { Education resources which aid } \\
\text { communication of hazard and risk } \\
\text { information, often developed } \\
\text { specifically for non-expert } \\
\text { stakeholders. These can include } \\
\text { pamphlets and brochures, websites, } \\
\text { warning signs, videos, and public } \\
\text { talks and meetings. }\end{array}$ & $\begin{array}{l}\text { Auckland } \\
\text { Volcanic Field, } \\
\text { Tongariro }\end{array}$ & DOC (2012), Wilson et al. (2014) \\
\hline
\end{tabular}

distinguish areas of hazard, exposure, vulnerability and risk (Sparks et al. 2013). Ballistic hazard map zones may be classified by maximum travel distance of particles (either any size or a specific sized particle; Alatorre-Ibargüengoitia et al. 2012), number of ballistic impacts per unit area (Gurioli et al. 2013), probability of a specific size of ballistics reaching a given area (Artunduaga and Jimenez 1997), or probability of a specific consequence occurring e.g. death, injury, damage (Fitzgerald et al. 2014). A good example of a ballistic hazard map that follows the best-practice steps above was created by Alatorre-Ibargüengoitia et al. (2012) of Popocatepetl Volcano, Mexico. In this example, eruption history and frequency of occurrence are used to define three eruption scenarios (High: VEI 2-3 (as they are more frequent), Intermediate: 4, and Low: 5 (though an eruption of this size would affect more people and impact a larger area, it has a much lower likelihood of occurring). The maximum travel distance of ballistic projectiles from each scenario (based on field and model distributions) is then used to define the extent of the hazard zones. Additionally, the map identifies nearby towns and roads exposed to ballistic hazard.

In many instances, it may not be possible or warranted to complete all of the steps involved in an ideal risk assessment. For example, Gareloi Volcano, Alaska is located on an uninhabited island, thus a detailed ballistic hazard assessment was not the priority of initial hazard assessments. Coombs et al. (2008) explore the eruptive history of Gareloi Volcano, though eruption frequency is only narrowed down to one eruption every 20-50 years and is not broken down into eruption magnitudes. Ballistic hazard is confined to 
one hazard zone (a $5 \mathrm{~km}$ concentric radius around the vent), whose extent is based on Blong's (1996) assessment that ballistics generally do not travel further than $5 \mathrm{~km}$ from vent. It is also mentioned that recent ballistic distributions have not travelled further than several hundred metres from vent. Neither a deterministic or probabilistic approach was taken, instead a value was adopted from other eruptions around the world.

Very few studies exist on ballistic risk or vulnerability. We summarise the three that could be found. Booth (1979) presents an example of a volcanic risk map for the La Primavera Volcanic Complex, Mexico. Though ballistics are included, they are not ascribed a probability of occurrence, instead, one zone at risk of ballistic fall is defined by the maximum travel distance for ballistics up to $0.1 \mathrm{~m}$ in diameter. The equation that Booth used to calculate risk includes probability of occurrence, indicating that eruption frequency has been examined; however, neither the probability used nor the description of prior eruptive history are provided in the publication. Thus, though an end-product of a risk map is produced, the process itself is not documented. Pomonis et al. (1999) utilise the Blong (1981) impact energy thresholds for roof perforation to assess building vulnerability from an eruption of Furnas Volcano, the Azores. Two risk zones are assigned (moderate and high) based on the statement that ballistics generally land within $5 \mathrm{~km}$ of the vent, but sometimes up to $10 \mathrm{~km}$. The study only considers one eruption (the last major eruption), thus is lacking eruption frequency and magnitude, and does not provide any probabilities of building damage occurring. Building vulnerability to ballistic impact has been assessed by Jenkins et al. (2014) for Kanlaon and Fogo volcanoes (Philippines and Cape Verde, respectively) using estimates of energy required to penetrate roof materials by Blong (1981) and Pomonis et al. (1999). This study, however, focussed only on the vulnerability of the built environment and did not include an overall assessment of hazard or risk. Eruption frequency and magnitude, the extent of past ballistic distributions, and modelling of possible future trajectories were not investigated.

Assessments may also vary depending on the state of the volcano. Volcanoes in a state of quiescence allow for (and call for) more in-depth, preferably probabilistic, assessment to be completed, ideally following the steps outlined earlier. However, quiescent volcanoes may not be the primary target for in-depth assessment. Conversely, renewed volcanic activity, especially when unexpected, urgently demands rapid hazard assessments which may, as a result, be too simplistic, overly conservative or lacking sufficient detail to be considered complete. They also need to be focussed on the range of scenarios presenting the risk in that crisis (e.g. from one vent), rather than the entire background risk from that volcano (e.g. from multiple vents). Leonard et al. (2014) describe the process of creating a crisis hazard map for the 2012 Upper Te Maari eruption, comparing this to the existing background hazard map. In the case of a volcano in a state of unrest, assessments may be limited by the availability of safe locations to survey, and this is especially likely once an eruption episode has commenced as evident during the 2012 Upper Te Maari, Tongariro eruptions and assessments presented later. Odbert et al. (2015) have been developing updateable hazard forecast estimates using Bayesian belief networks, which may help to improve rapid hazard assessments in times of crisis.

\section{Communication and Risk Management Strategies}

Effective communication is essential in managing ballistic hazard and risk (Barclay et al. 2008; Leonard et al. 2014). Science needs to be communicated to decision-makers, stakeholders, and the public and understood and absorbed by them so they can make informed decisions. Similarly, the public, stakeholders, and decision-makers should communicate to scientists what type of information they need to make decisions relevant to their situations. Ballistic communication 
methods used at volcanoes include hazard and risk assessments, hazard maps, volcano monitoring and research, real-time warning systems, volcanic alert levels; volcano warnings, alert bulletins and communication with agencies; response exercises, education materials, response plans, exclusion and evacuation zones, instructions and signage for what to do in the event of an eruption around the volcano, community engagement, educational materials, and land-use planning and infrastructure design. These methods typically fall under four aspects of emergency management: Mitigation (Reduction), Preparedness, Response and Recovery (UNISDR 2009). Methods must also be integrated with the management of other risks, ideally in one cohesive approach. Ballistic communication strategies will also vary with eruption frequency, the risk context (quiescence or crisis; Fig. 2), whether volcanoes are frequently visited or inhabited, and the availability of resources. This equally applies to volcanoes at which ballistics are/are not the main hazard.

Effective risk management is built on communication, hazard education and engagement with the at-risk communities (Johnston et al. 1999, 2000; Paton et al. 2001; Twigg 2002; Gregg et al. 2004; Leonard et al. 2008; Dohaney et al. 2015). Appropriate risk management actions by stakeholders, emergency managers and the public require an adequate perception of the risk and the correct actions to take in a crisis, with perception dependent on the hazard information received and exposure to impacts (Johnston et al. 1999; Leonard et al. 2014). Knowledge and understanding of volcanic hazards allows individuals to better decide whether to undertake preparedness and response measures, and if so,

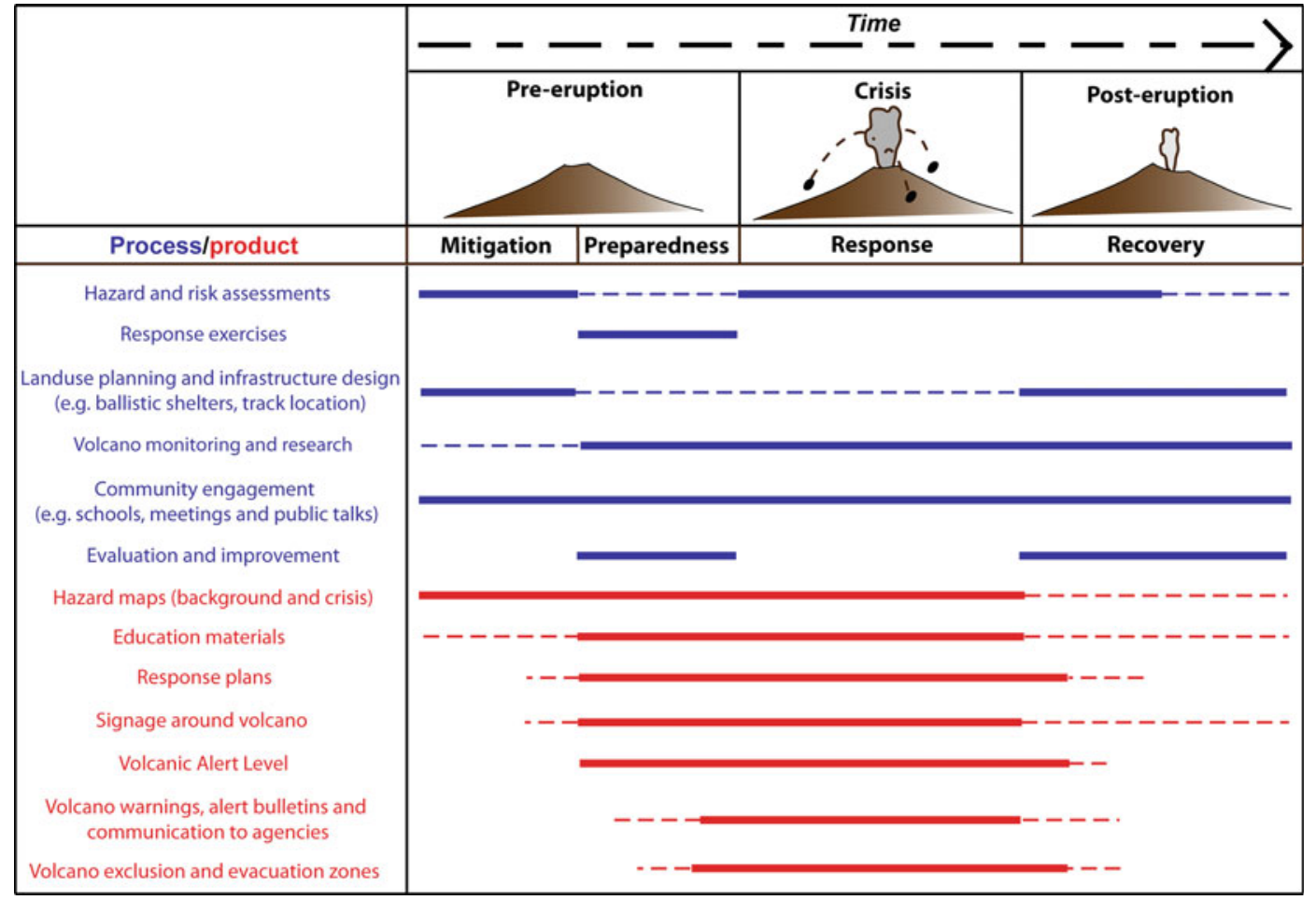

Fig. 2 Various ballistic hazard and risk communication processes (blue) and products (red) implemented over the changing state of the volcano and the stage of risk or emergency management. The level of activity/importance is indicated by line style, with solid lines indicating higher use or importance 
which are required, thus reducing their vulnerability to the hazard(s) (Siegrist and Cvetkovich 2000; Paton et al. 2008; Bird et al. 2010).

Scientific information can be misunderstood, misrepresented or distorted when passed from scientists to end-users (stakeholders, emergency managers and the public; Barclay et al. 2008). This can occur when end-users do not comprehend or are unaware of the science being presented, the information is not what is actually needed by end-users, the science is communicated poorly to end-users, or there is a lack of trust between groups (Haynes et al. 2007). All groups therefore need to communicate with each other, preferably prior to a volcanic crisis, with communication products tailored to the audience (Haynes et al. 2007; Leonard et al. 2008). Following the 1979 eruption of Mt. Ontake, Japan the National Research Institute for Earth Science and Disaster Prevention in Japan (NIED, though now renamed to National Research Institute for Earth Science and Disaster Resilience) completed a report recommending: regulations on development and land-use, building of ballistic shelters and evacuation facilities, and the development of emergency plans, as an eruption in the summer hiking season would likely result in human casualties (NIED 1980). However, the report may not have been suitable or communicated well to the local municipalities responsible for disaster management as these recommendations were not adopted prior to the 2014 eruption, indicating the need for communication to ensure the information is relevant, understood and acted upon (Barclay et al. 2008; The Japan News, 27/10/2014). Communication delivered jointly by scientists and the local community is also advisable as community members may be better trusted and better communicators to their community than scientists in isolation. Users must be able to trust the source of the information being released as well as how and what is presented (Slovic 2000; Haynes et al. 2008). It is also therefore important for scientists and emergency managers to be honest about what is/is not known to maintain credibility and trust (Lindell 2013).
Best practice suggests the use of multiple sources to disseminate hazard and risk information as preferred forms of media accessed for information vary (Sorensen 2000; Mileti et al. 2004; Haynes et al. 2007; Bird et al. 2010). The public's response to volcanic hazard communication is influenced by the content and attractiveness of the message (which should include a description of the hazard, its impacts, hazard extent, and advice on what to do and when), how comprehensible it is, and the frequency and number of channels the message is received from, as well as the extent of public belief that safety actions are possible and will be effective (Leonard et al. 2008; Sorensen 2013).

\subsection{Ballistic Communication Processes and Products in Different Risk Contexts}

\subsubsection{Volcano Quiescence}

Communication and risk management methods vary with changing eruptive states. In times of quiescence focus is placed on risk mitigation and preparedness, with access generally allowed into the hazard zone. In terms of ballistics this includes the completion of ballistic hazard and risk assessments; volcano monitoring and research; land-use and building planning i.e. the building of ballistic shelters capable of withstanding ballistic impacts or the reinforcement of existing structures to specific building standards, and the choice of location for hiking trails, viewing platforms or other visitor facilities; the creation of well distributed hazard maps with instructional text with what to do or where to go in an event of an eruption; and engagement with the local communities including exercises and evaluation (Fig. 2).

Hazard and risk assessments are useful starting points for all communication and management strategies as the nature, extent and consequences of the hazard need to be understood prior to any decisions being made. The assessment should be made available to relevant decision makers, with the authors and science 
advisors available to advise or answer questions about the assessments. Scientists/authors should always strive to be transparent in their methodology. Transparency builds trust and credibility. It is important that stakeholders know the limitations of the information presented to them and/or informing decisions which affect them. It may not be needed or appropriate for the methods to be presented to the stakeholders in depth but instead it be communicated that they are available if requested. However, it is imperative to think of the risk context when making these decisions, as every situation is different. Methods and assessments should also be made fully available to other scientists so that these methods can be adopted at other volcanoes if chosen, which would increase best-practice and encourage similar and comparable methodologies. These assessments also need to be communicated to the public so that they can make informed decisions about the hazard and risk in the area they choose to enter as well as what steps they need to take to protect themselves.

The main way assessments are communicated is through a map (Haynes et al. 2007). Ballistic hazard maps are rare as they are typically not the only hazard produced in an eruption. Instead ballistics are typically included in 'all-hazard' or 'multi-hazard' maps (Fig. 3) depicting the general hazard for all active vent(s) (Neal et al. 2001; Hadisantono et al. 2002; Mount Fuji Disaster Prevention Council 2004; Kagoshima City 2010; Leonard et al. 2014). Ballistics are usually represented by one hazard zone, often based on the maximum or expected travel distance of a ballistic clast. This is, in part, because the public require concise, easily comprehensible information, rather than being distracted or overloaded with specifics of individual hazards (Haynes et al. 2007; Leonard et al. 2014). An effective hazard map for the public contains clear information on what are the consequences of the hazard(s), where they occur, and what to do (Leonard et al. 2014). For ballistics, impacts may be death or injury; impact locations are usually within $5 \mathrm{~km}$ of the vent; and advice may include "if ballistics are landing around you, move out of their oncoming path, seek shelter and make yourself a small target." Advice on actions to be taken may vary at different volcanoes, although it would be beneficial if messages are consistent across all volcanoes to reinforce actions and increase the likelihood of people following the correct actions. For this to occur, testing of suggested actions would be required to ensure that the safest and most successful measures are being advised. For example, where frequent Strombolian eruptions are the main source of ballistics, it may be possible to watch the low velocity ballistics and move out of their path. However, in many other eruption styles multiple particles may be ejected rapidly toward a person, presenting a situation in which dodging one ballistic may put you in the path of another. It may be more beneficial to make yourself as small a target as possible, seek shelter and use your backpack as a protective shield. Additionally, ballistics may be accompanied by a surge as seen in the 2014 Mt. Ontake (Kaneko et al. 2016; Oikawa et al. 2016) and August 2012 Te Maari eruptions (Breard et al. 2014), inhibiting the ability to see ballistics until it is too late to act.

Map design should also take into account the effect of map properties on communication (understanding/comprehension) such as data classification, basemap or image, colour scheme (e.g. for colour blind readers), content, and key expression (Haynes et al. 2007; Thompson et al. 2015). Haynes et al. (2007) evaluated the effectiveness of volcanic hazard maps as communication tools on Montserrat, West Indies and found that the use of aerial photographs as a basemap improved people's ability to comprehend hazard information compared to traditional contour basemaps. In general, it has been found the public do not comprehend maps well and professional design input guided by iterative evaluation of map comprehension is wise (Haynes et al. 2007; Thompson et al. 2015). In contrast to the public, more specialist stakeholders such as infrastructure managers may require more detailed and hazard specific information about the impacts, location and recommended actions to inform decisions on land-use and building strength e.g. ballistics impacts in zone 1 can be expected to have sufficient energy 


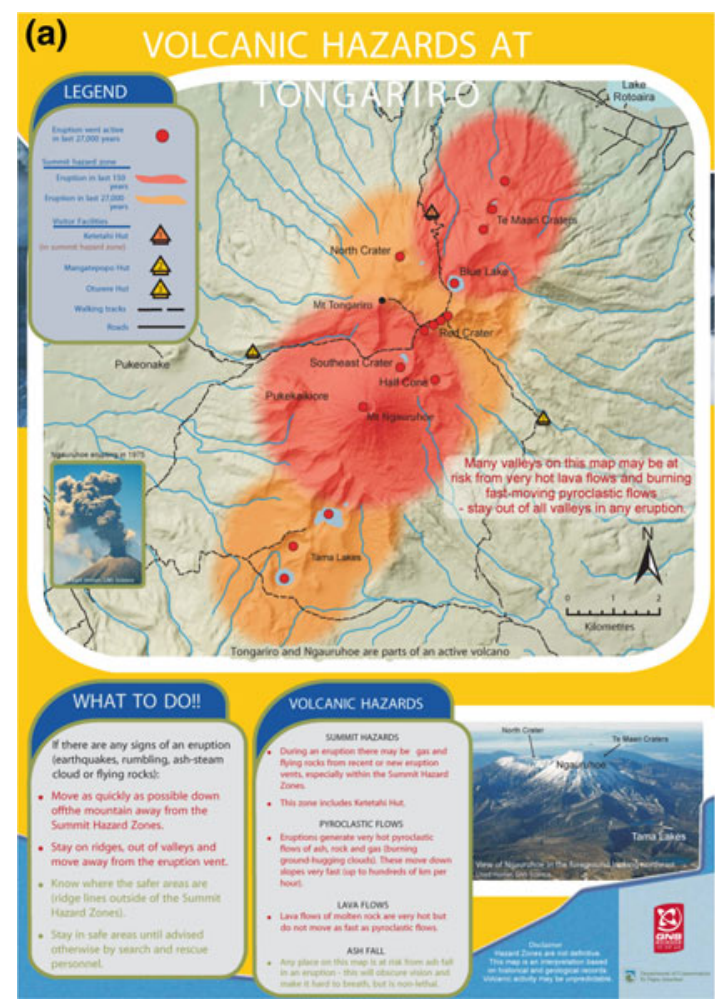

(b)
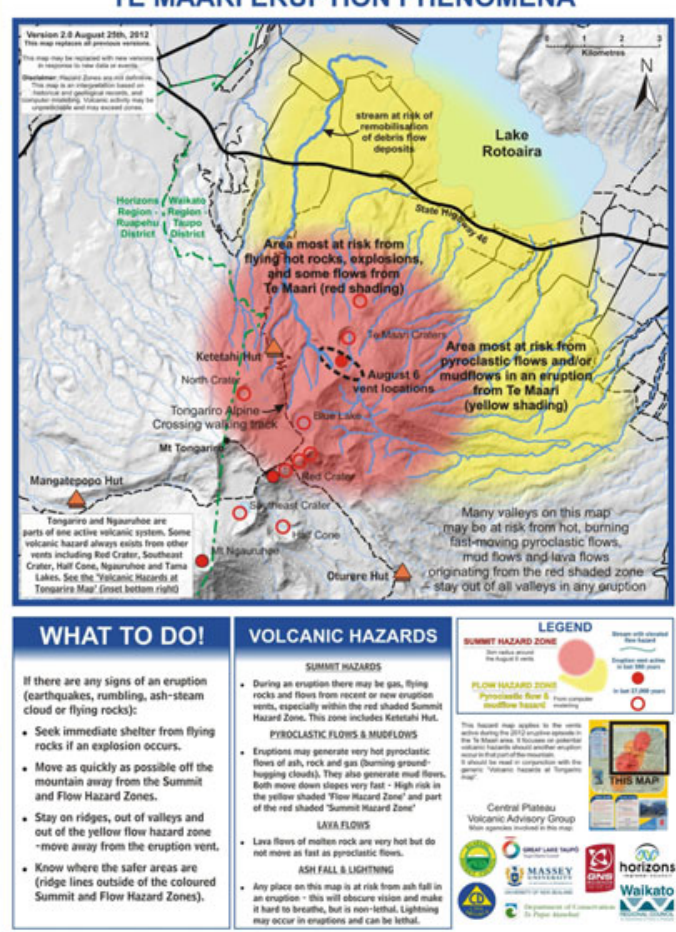

crisis hazard map following the 2012 eruptions of Upper Te Maari (GNS Science 2012). Note that map A is shown as an inset on map B with an explanation as to the complementary but differing nature of the two communication products to cause severe damage to nearly all types of infrastructure below a certain design standard. Multiple zones of different impact intensity may be shown (e.g. travel distance, density of impacts in an area, size and or energy of expected ballistics in given scenarios). All end-user maps should successfully balance adequate detail and maximum clarity. Hazard maps and additional information should be made available and accessible to the public, and if different maps are made for, or directed to, different audiences their content must be consistent. Public availability may include being posted on signs around the volcanoes entrance(s), in a pamphlet or similar printed media at tourist facilities (e.g. information centres, tourism businesses, hotels, backpackers accommodation, transport operators), and on relevant websites such as volcano observatories and those charged with managing natural hazards.

Additionally, community engagement and participation in meetings with scientists and managers is encouraged as a means of risk communication, and discussion around management strategies, especially for communities at risk (i.e. tourism providers and those living near or on the volcano) (Cronin et al. 2004; Williams and Keys 2013). Ballistic hazards lend themselves to this type of community engagement because many open system volcanoes that may be constantly erupting but not considered to be in a state of volcanic crisis (e.g. Stromboli, and Yasur) have frequent ballistic-producing eruptions that provide an attraction to tourists and employment for the local community. Ballistics at these constantly erupting volcanoes provide 
tangible hazards that the community can both relate to and provide valuable observational data on. Meetings should be sufficiently regular to update residents when the status of a volcano is changing and to remind them when necessary of the hazards and risks. Briefing those new to the area, especially the transient visitor, may be the biggest challenge. Engagement allows the community to be prepared in the event of an eruption and to know what to do in the event that they are within hazard areas.

\subsubsection{Volcanic Crisis}

In a volcanic crisis (when the volcano is showing signs of unrest or is in eruption) communication and emergency management processes and products move toward response (Fig. 2). Real-time warning systems triggered by monitoring equipment, such as the EDS (Eruption Detection System) system installed on Mt. Ruapehu, New Zealand (Leonard et al. 2008), are used to communicate an eruption to those in the immediate vicinity. Wider communication occurs when an event is communicated from monitoring equipment to scientists, then onto emergency managers and decision-makers. Part of this process is the release of alert bulletins/warnings to advise the public of unrest, eruption phenomena, affected areas, and should always include instructions on what to do. Alert bulletins, existing hazard maps and risk and hazard assessments provide emergency managers with information to make decisions on limiting access to parts of the volcano. In the case of ballistics, limits or restrictions on access or development are usually achieved via creation of an exclusion zone, typically $1-4 \mathrm{~km}$ in radius (Kagoshima City 2010; Jolly et al. 2014b), or by reducing exposure by limiting the time spent or number of individuals allowed within a zone (Bertolaso et al. 2009).

During the crisis, hazard maps are typically updated and hazard and risk assessments modified. Maps are generally event-specific and only used over a short time-frame, reverting back to the original background hazard maps once the crisis period is over (Leonard et al. 2014; Fig. 3). However, ballistic hazard mapping during a

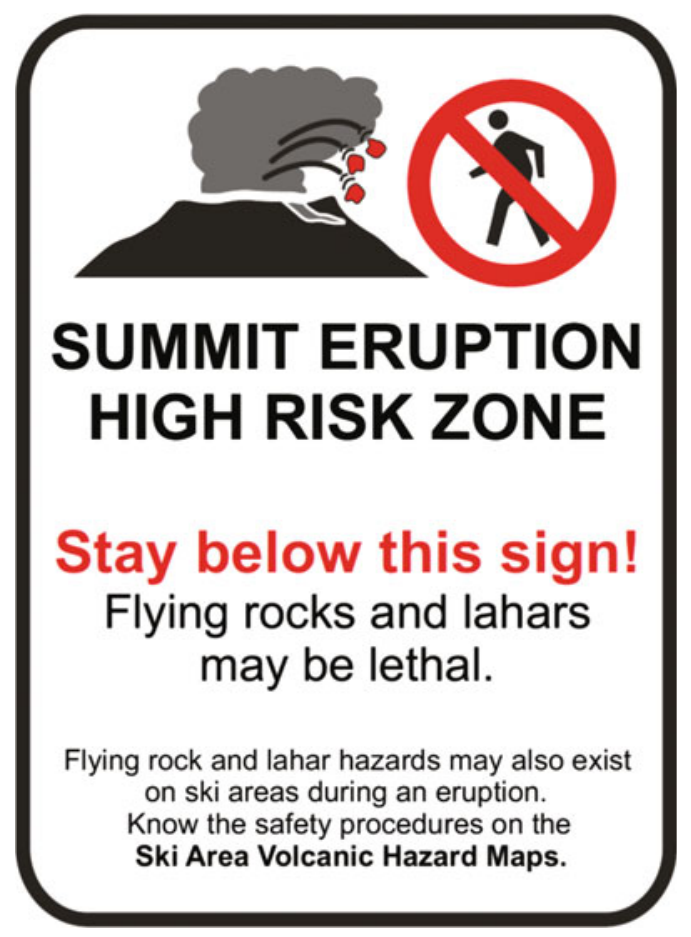

Fig. 4 Crisis communication sign temporarily used at Ruapehu volcano following a small eruption in 2007, while it was considered there was an elevated risk of further eruptions

crisis can be limited by access restrictions due to the possibility of further eruptions, though as time progresses more detailed mapping is able to be completed (Fitzgerald et al. 2014). The ongoing work by Odbert et al. (2015) in developing a real-time updateable probabilistic risk assessment may prove useful in these situations. The event-specific hazard maps are generally shared around the various media outlets (e.g., television, radio, newspapers, Facebook, Twitter) to inform the public of the updated hazard, as well as through the usual means of communication. They may be augmented by specific life safety signage (e.g. Fig. 4).

Meetings and consultations with local communities, emergency managers and other stakeholders should also occur during and following volcanic crises. The objectives of such meetings are to update communities on the evolving eruptive hazards, build relationships and trust, reduce any miscommunication or misinformation 
passed along, and to make sure the information being presented is what the end-members need (Barclay et al. 2008; Bertolaso et al. 2009).

Communication of ballistic hazards and risk management vary at frequently erupting volcanoes that commonly enter in and out of crisis, such as Sakurajima in Japan. Access is generally controlled at all times (even during periods of quiescence), sometimes with permanent restriction zones in which nobody is allowed to enter due to the risk of being struck by ballistics (Kagoshima City 2010). In these cases different hazard scenarios may be pre-prepared and communication strategies reused with a population that is well educated about the volcano.

\subsection{On-Going Challenges in Ballistic Risk Communication}

Many volcanoes are tourist destinations with associated tourist facilities such as ski fields, accommodation and walking tracks (Erfurt-Cooper 2011). One challenge of communicating ballistic risk is to transient populations, especially tourists and other visitors. Tourists spend only a short amount of time in areas (hours to weeks) and often have little knowledge of the hazards or the available protection resources (Murphy and Bayley 1989; Drabek 1995; Burby and Wagner 1996; Bird et al. 2010). They often rely on tourism operators/employees/guides to inform them of volcanic hazards and the correct actions to take in an eruption (Leonard et al. 2008; Bird et al. 2010). This is evident at Yasur Volcano, Vanuatu where guides are frequently relied on to communicate ballistic hazard and safe areas to approach around the volcano, and at Tongariro Volcano, New Zealand where transport operators can give important information to $85 \%$ of all those hiking the Tongariro Alpine Crossing (TAC). However, tourism staff may also be somewhat transient, meaning that they may need to be regularly educated, trained or updated on volcanic hazards, appropriate responses and emergency procedures so that they can pass the message down to their patrons (Leonard et al.
2008; Bird et al. 2010; Williams and Keys 2013). Additionally, education material such as pamphlets and hazard maps on volcanic hazards should not only be available at tourism businesses but mechanisms should be in place that ensure that the hazard information is relayed to these transient populations.

Another ongoing challenge in communicating ballistic hazard is the lack of warning time associated with events that have little precursory activity, in which ballistics are typically one of the main hazards. In this scenario volcanic alert levels and bulletins may not be released prior to eruption. Instead, visitors and stakeholders would have to rely on their knowledge of the potential hazards and the response actions to take, especially if there are no real-time warning systems. This places more emphasis and weight on the availability of background hazard maps with messaging covering actions in events up to this size, signage around the volcano (in language(s) appropriate for the audience to comprehend, especially if there is a large proportion of visitors who speak a different language), on pamphlets distributed to businesses and visitors actually reading them, and through communication with their guides. Many visitors to the TAC still assume that they do not need to be concerned because they expect the area to be closed if it is unsafe or to be advised it was unsafe (Keys 2015).

We present the various ballistic risk management and communication approaches taken at four volcanoes: Upper Te Maari, Tongariro Volcanic Complex, New Zealand; Yasur Volcano, Vanuatu; Sakurajima Volcano, Japan and Mt. Ontake, Japan (Table 2). These volcanoes have been chosen for their variation in: frequency of eruption (Sakurajima and Yasur frequently erupt, while Upper Te Maari and Mt. Ontake have longer repose periods), available resources (Yasur has less monitoring equipment and hazard information available than the other three examples), eruptive styles-Yasur predominantly erupts bombs from small Strombolian eruptions; compared with phreatic eruptions from Mt. Ontake and Upper Te Maari and Vulcanian eruptions from Sakurajima that erupt blocks over a larger area, and the similarity in eruptions but with very 
Table 2 Comparison of the four case studies and their risk management and communication strategies

\begin{tabular}{|c|c|c|c|c|}
\hline & Upper Te Maari & Yasur & Sakurajima & Mt. Ontake \\
\hline Dominant eruptive style & Hydrothermal & Strombolian & Vulcanian & Phreatic \\
\hline Recurrence interval & $\sim 16$ years & Frequently erupting & $\begin{array}{l}\text { Frequently } \\
\text { erupting }\end{array}$ & $\sim 13$ years \\
\hline $\begin{array}{l}\text { Duration of precursory } \\
\text { activity }\end{array}$ & $\begin{array}{l}3 \text { weeks of seismicity, } \\
5 \text { min of increasing } \\
\text { seismicity }\end{array}$ & & & $\begin{array}{l}\text { 2014: } 16 \text { days } \\
\text { seismicity, } 11 \text { min } \\
\text { increasing seismicity } \\
\text { and inflation }\end{array}$ \\
\hline Number of visitors & 100,000 visitors/year & 20,000 visitors/year & $\begin{array}{l}3,702,000 \\
\text { visitors/year }\end{array}$ & $\begin{array}{l}\text { Hundreds of visitors } \\
\text { per day }\end{array}$ \\
\hline $\begin{array}{l}\text { Hazard map with } \\
\text { ballistics }\end{array}$ & Background and crisis & Yes & Yes & Two background maps \\
\hline $\begin{array}{l}\text { Volcano exclusion and } \\
\text { evacuation zones }\end{array}$ & Yes & Yes & Yes & Yes \\
\hline Volcanic Alert Levels & Yes & Yes & Yes & Yes \\
\hline Education material & Yes & Yes & Yes & Yes \\
\hline Volcano monitoring & Yes & Yes & Yes & Yes \\
\hline $\begin{array}{l}\text { Land-use planning and } \\
\text { infrastructure design }\end{array}$ & $\begin{array}{l}\text { Ketetahi Hut (not } \\
\text { reinforced). TAC runs } \\
\text { through summit } \\
\text { hazard zone }\end{array}$ & $\begin{array}{l}\text { No shelters or buildings. } \\
\text { Track and viewing } \\
\text { platforms along rim of } \\
\text { volcano }\end{array}$ & $\begin{array}{l}\text { Concrete } \\
\text { shelters around } \\
\text { island, } \\
\text { evacuation } \\
\text { ports }\end{array}$ & $\begin{array}{l}\text { Mountain lodges and } \\
\text { shrines (not } \\
\text { reinforced). Tracks } \\
\text { near active craters }\end{array}$ \\
\hline Community engagement & Yes & In progress & Yes & Yes \\
\hline Response exercises & No & No & Yes & Yes \\
\hline $\begin{array}{l}\text { Evaluation and } \\
\text { improvement }\end{array}$ & $\begin{array}{l}\text { Assessments updated } \\
\text { post-eruption, creation } \\
\text { of crisis hazard map }\end{array}$ & $\begin{array}{l}\text { Currently assessments } \\
\text { and maps are being } \\
\text { updated }\end{array}$ & $\begin{array}{l}\text { Last update of } \\
\text { hazard map } \\
\text { was in } 2010\end{array}$ & $\begin{array}{l}\text { New hazard map } \\
\text { released November } \\
2015\end{array}$ \\
\hline Signage around volcano & Yes & Yes & Yes & Yes \\
\hline $\begin{array}{l}\text { Volcano warnings, alert } \\
\text { bulletins and } \\
\text { communication with } \\
\text { external agencies }\end{array}$ & Yes & Yes & Yes & Yes \\
\hline
\end{tabular}

different consequences between Upper Te Maari and Mt. Ontake. Additionally, all of these volcanoes are relatively accessible and attract large numbers of tourists each year.

\section{Case Studies}

\subsection{Eruptions of Upper Te Maari, Tongariro, New Zealand}

On the 6th August 2012, Upper Te Maari Crater, one of the many vents on Tongariro volcano, New Zealand, erupted for the first time in over 100 years (Scott and Potter 2014). The hydrothermal eruption produced multiple pyroclastic surges, an $\sim 8 \mathrm{~km}$ high ash plume and ejected thousands of ballistic blocks (Fitzgerald et al. 2014; Lube et al. 2014; Pardo et al. 2014). Blocks were distributed over a $6 \mathrm{~km}^{2}$ area, affecting $\sim 2.6 \mathrm{~km}$ of the popular Tongariro Alpine Crossing (TAC), a walking track frequented by around 100,000 people a year (Fitzgerald et al. 2014). Additionally, Ketetahi Hut, an overnight hut along the TAC, was severely damaged by ballistics. Fortunately, the eruption occurred at night, in winter (the low season) and in bad weather, resulting in no hikers along the TAC or staying at Ketetahi Hut (both around $1.5 \mathrm{~km}$ away from the vent and well within the impacted area). A smaller eruption 
followed on 21 November 2012, though ballistics and pyroclastic surges were confined to within a well posted risk management zone $1 \mathrm{~km}$ from the vent and did not affect the TAC.

Ballistics were a known hazard from the active vents of Tongariro, witnessed in the 1974-5 Ngauruhoe eruptions (Nairn and Self 1978). As such they were described on the background hazard map for the volcano (Fig. 3a). The map, published in 2007, consists of a summit hazard zone around each active vent, encompassing gas and ballistics at radii of 2-3 km for different vents based on experience of ballistic ranges in past eruptions at Tongariro National Park. Work is underway to develop ballistic and life safety models to better inform zone radius. Pyroclastic density currents (PDC's) and lava flows are not included in a hazard zone but are mentioned as a possibility in all valleys. Ashfall is stated as a hazard that could occur any place on the map. Text is provided, with instructions including to move quickly down off the mountain and away from summit hazard areas, though ballistics-specific advice was not provided (GNS Science 2007). The background hazard map with associated instructions was permanently posted at the entrances to the walking tracks up the volcano, was available on the GNS and DOC websites as well as on flyers at many of the tourist hubs (Leonard et al. 2008, 2014). The TAC hiking track cuts through most of the summit hazard zones, where access has been open at background levels. One hut, Ketetahi Hut, is located within the summit hazard zone, though is not reinforced to protect against ballistic impact.

Unrest was observed at the volcano up to three weeks before the eruption, initially in the form of increased seismicity and then increased magmatic gas content (Jolly et al. 2014a). In response the Volcanic Alert Level was raised from 0 to 1 (indicating unrest). Seismicity declined in the days prior to eruption and thus the TAC remained open to tourists (Jolly et al. 2014b), with seismicity reoccurring only $\sim 5 \mathrm{~min}$ before the event (Jolly et al. 2014a). In the build-up to the eruption, a decision was made to complete response plans and create a crisis hazard map initially for the whole volcanic massif with some focus on the northern flank of Tongariro. However, it was not publically available before the August 6th eruption (Leonard et al. 2014). GNS volcanic alert bulletins were also produced, communicating updates on the precursory phenomena observed at Tongariro (Volcanic Alert Bulletins TON-2012/01-04; Fig. 5e). Meetings and other discussions were held with the local residents and businesses involved with the TAC to discuss the situation and future scenarios. Being wintertime, there was very little use of the track. As there was no one on the hiking trail during the eruption it is difficult to assess the success of the hazard communication strategies, and these strategies would have been different during summer months with heavy track use.

Following the August event, some of the local population evacuated for the night and the TAC was closed for two months due to the risk of further eruption. Within this two-month period an updated hazard and risk assessment was completed (Jolly et al. 2014b). This involved a combination of reviewing the eruptive record to understand eruption frequency and magnitude, and expert elicitation by GNS staff (the institute responsible for monitoring volcanoes and assessing their hazard/risk) working closely with the land manager (Department of Conservation) to produce three possible future eruption scenarios (a 21 November size eruption, a 6 August size eruption, and a magnitude larger eruption) and associated probabilities of these occurring. Probabilities were re-assessed every week immediately after eruption, which was subsequently extended to every month, then every three months as time passed. Hazard extent was considered for ballistics and PDC's for each scenario, exposure time along the impacted area, and the vulnerability (probability of fatality) of an individual to each hazard (using the area of hazard around an individual impact for ballistics, and the presence of a person in the path of a PDC), to calculate the combined risk of fatality for all scenarios (Jolly et al. 2014b).

Initial assessments suggested that ballistics were the main hazard to life from the eruption, though detailed mapping was not able to be carried out until months later when risk levels 

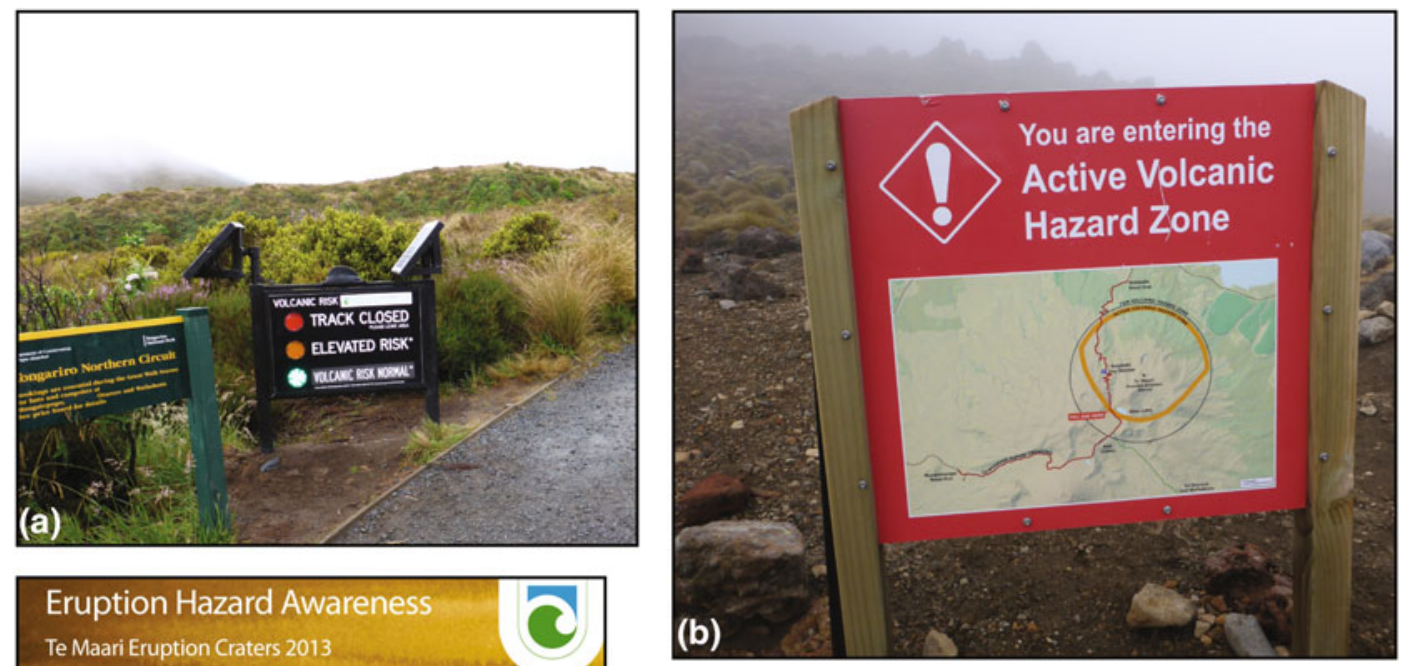

Eruption Hazard Awareness
Te Maari Eruption Craters 2013

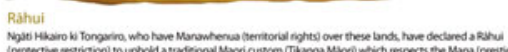

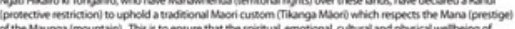

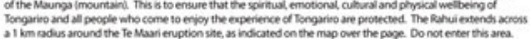

Read carefully:

- The ano inom as Upper Te Mani Cate

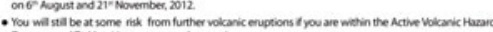

Cor

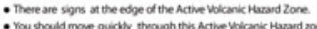

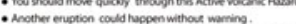

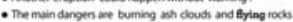

Should an eruption occur

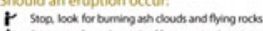

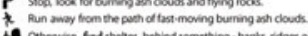

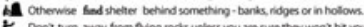

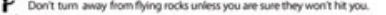

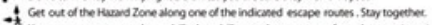

Other hazards

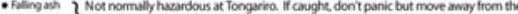

- Gas $\}_{\text {area as quidly as possible }}$

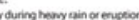

Electronic lights and other signs.

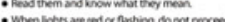

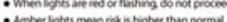

- Amber lights mean ras is higher than nomal

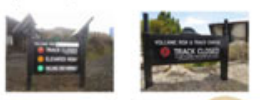

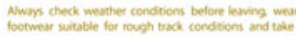

(c)

Department of

Conservation

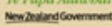

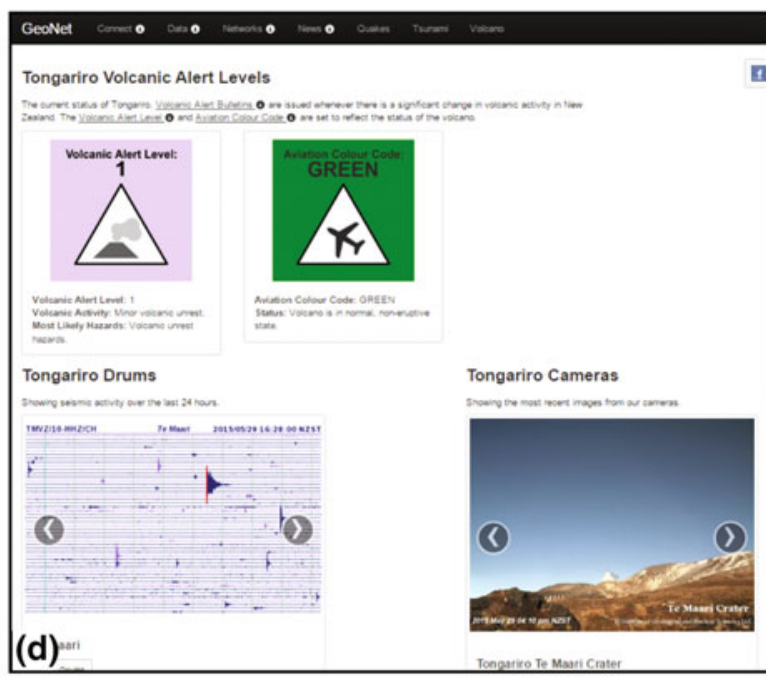

Volcanic Alert Bulletin TON-2012/07 - Tongariro Volcano

7 August 2012, 12:15 pm . Update; Alert Level remains at Level 2; Aviation Colour Code changed to Orange

View the Tongarito current activity page

What to do in a volcanic eruption

A short lived phreatic enuption occurred at the Te Mari craters area on Mount Tonganio at approximatey 11:50 pm last night (Monday, 6 August

2012. Activity at the present time consists of steam clouds and some small earthquakes. Enjptive activity is low level but could recommence at

any time.

Observations of Mount Tongariro this moming by GNS Science are that eruption activity has subsided White steam clouds were observed at the historically active Te Mari craters area but poor weather conditions at the time obscured a direct view of the active vent(s). There have been no lahars or pyroclastic flows or lava flows.

Our analysis of seismic data is that there was an explosive eruption lasting only a minute or two, followed by a series of discrete smal earthquakes over the next few tens of minutes. No volcanic tremor occurred in the days preceding the eruption. nor has any occurred since then

In it is too early to predict the next series of events, but we expect heightened activity may continue for several weeks. There are likely to be specific (e) signals of future magma movement beneath the volcano and we continue to monizor the situation through the GeoNet volcano-seismic network of

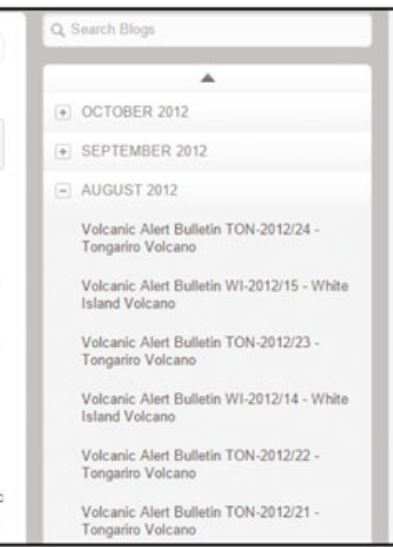


Fig. 5 Risk communication methods used at Tongariro, New Zealand. a Electronic signs communicating risk level and track closure at entrances to the volcano and where it crosses the AVHZ. b Signs advising area of increased hazard including a track-specific AVHZ hazard map. c Additional information on volcanic hazards at Tongariro (including ballistics), initially handed out to all

had decreased (Fitzgerald et al. 2014; Jolly et al. 2014b). The Department of Conservation (DOC), the agency responsible for hazard and risk management at Tongariro, began to implement risk management as part of a recovery programme. The risk assessments by Jolly et al. (2014b) became an important tool for making decisions about reopening. A new, event-specific Te Maari hazard map was created using mapped deposits and the most likely hazard scenarios, in which the main hazard zone was increased to a $3 \mathrm{~km}$ radius (choosing the larger potential radius based on historic events) down-slope and deliberately renamed the Active Volcanic Hazard Zone (AVHZ) to distinguish it from the former map (Fig. 3b). It included ballistics, explosions, pyroclastic density currents, lahars, gas and rockfall (Jolly et al. 2014b). The accompanying text to the crisis hazard map was also updated, with a ballistic specific instruction to 'seek immediate shelter from flying rocks if an explosion occurs' (GNS Science 2012). The map was released to the public alongside a Volcanic Alert Bulletin describing the changes made to the map and the source of the data (Volcanic Alert Bulletin TON-2012/23). This was distributed to the media (print, television, web and radio) to inform a wider audience (Leonard et al. 2014). Additionally, the map was posted at either ends of the track and where it crossed the boundaries of the AVHZ. Cordons, initially manned, were established at either ends of the TAC to prevent hikers from entering. Later, the cordon was moved to Emerald Lakes (on the edge of the $3 \mathrm{~km}$ Volcanic Hazard Zone) as the track was partially reopened. With declining risk of further eruption (based on the trend of the eruption probability estimates made by GNS to estimate how the expert elicitation might evolve over time), the hikers, provided on Department of Conservation website. d GeoNet website showing monitoring data such as Volcanic Alert Level, seismic drums and visuals of the volcano. e A Volcanic Alert Bulletin issued on the GeoNet website and distributed to media following the 2012 Upper Te Maari eruption

track was fully opened $5 \frac{1}{2}$ months after the 21 November eruption.

DOC also published educational information on the eruption hazard at Te Maari including further advice on actions to take in an eruption (Fig. 5c). This included to 'stop, look for flying rocks', to 'find shelter behind something — banks, ridges or in hollows', to not turn away from 'flying rocks unless you are sure they will not hit you' and to 'get out of the Hazard Zone along one of the indicated escape routes' (Department of Conservation 2012). In October 2013 electronic warning signs were installed that informed hikers of the status of the volcano- - a red flashing light meant danger-turn back, orange elevated risk and green normal volcanic activity (Jolly et al. 2014b, Fig. 5a). A survey of 203 hikers on the TAC in March-May 2014 indicated that most people saw these signs when activated red and understood the messages irrespective of their native language (Keys 2015). A reinforced public shelter and warden's quarters was one option being considered to replace the damaged Ketetahi Hut. Now the favoured option is to replace it with facilities outside the AVHZ.

\subsection{Yasur Volcano, Vanuatu}

Yasur Volcano is a frequently erupting basaltic scoria cone located on Tanna Island, Vanuatu (Cronin and Sharp 2002). Strombolian and Vulcanian eruptions have been relatively continuous since 1774 (Eissen et al. 1991). Ballistics are the main hazard produced by these eruptions, responsible for multiple fatalities in the past (Baxter and Gresham 1997). Yasur is one of Vanuatu's main tourist attractions with some twenty thousand people visiting the crater rim 
each year. The vast majority of people are guided up the volcano by local guides to watch the eruptions occur, with a main viewing area only $150 \mathrm{~m}$ from the crater's inner rim. As the majority of people in the area are transient tourists, guides are often relied upon to relay hazard and risk information to their patrons. Volcanic alert levels (VALs) and bulletins are posted on the Vanuatu Meteorology and Geo-Hazards Department (VMGD) website when the behaviour of the volcano changes. These sometimes include hazards maps that provide the locations of where bombs have been observed or are likely to impact, and often caution the public to approach the crater or hazardous areas with care. Maps also urge visitors, tourist agencies and communities to seriously consider the information provided prior to ascending Yasur (Vanuatu Geohazards Observatory 2009). However, advice or instructions are not given for what to do if caught in an area where ballistics are landing. A hazard map is displayed at the carpark before the ascent up the cone, highlighting the 1999 lava bomb impact zone and the observation location for each volcanic alert level-as the alert level increases so does the distance of the observation position from the cone (i.e. restriction zones are emplaced). In addition, visitors to Yasur are warned by a sign to 'Think Safety' before ascending the crater rim, though no further instructions or information is provided. As it is frequently erupting, it is assumed that visitors accept the risk that they are entering into an active volcanic hazard zone.

An updated risk management framework has been developed from 2012 to 2016 including updated bulletins and VALs, background and safety (crisis) hazard maps, and tourist information including education and safety map information. This is associated with an upgrade of Vanuatu's active volcanoes to real-time warning (at the time of writing this included a seismometer and webcam on Yasur and daily OMI satellite monitoring of $\mathrm{SO}_{2}$ emissions; Vanuatu Geohazards Observatory 2014), supported by the New Zealand Aid Programme and GNS Science in partnership with VMGD. This integrated framework allows for pre-planning of safety zones related to ballistics and other hazards, and integration with warning products such as bulletins, VALs and tourist information. Ballistic zone ranges will initially be based on historic event ranges, but will be updated to include the modelling being developed in New Zealand, once available.

\subsection{Sakurajima Volcano, Japan}

Another frequently active volcano in which ballistics are a major hazard is Sakurajima Volcano, Japan. Continuous Vulcanian eruptions have occurred since 2009 from the andesitic composite cone (Japan Meteorological Agency 2013b). Sakurajima is constantly monitored by the Sakurajima Volcano Observatory and is considered to be one of the best monitored volcanoes in Japan (GSJ 2013). When activity changes, alert levels are posted on the Japan Meteorological Agency (JMA) website for the public to view. Many people live in close proximity to the volcano ( $\sim 4900$ within $5 \mathrm{~km}$ of the volcano) and millions visit the Kagoshima-Sakurajima area each year $(3,702,000$ in 2010; Japan Meteorological Agency 2013b), thus JMA and Kagoshima City released a volcanic hazard map with additional information in 2010. This map was distributed to local citizens and posted around the volcano. Three relevant zones are delineated on the map: the first is a $2 \mathrm{~km}$ radius (from the active craters) restricted area in which both residents and tourists are restricted from entering at all times; the second is $\sim 3 \mathrm{~km}$ away from the active vents showing the area expected to be inundated with volcanic bombs in a 'strong eruption', and lastly a $6 \mathrm{~km}$ radius extends around the active vents where 'volcanic rock' is likely to impact from a 'great eruption' (Kagoshima City 2010). Definitions for 'strong eruption' and 'great eruption' are not provided, nor is an explanation of the data that these zones are based on. The hazard map also includes societal components such as important landmarks i.e. schools and the visitor centre, and evacuation buildings and ports. The other half of the map consists of information on precursory 
phenomena likely to be felt and who to call if detected; how volcanic warnings will be disseminated and the measures needed to be taken; what the five volcanic alert levels are/what activity is expected and the consequent actions needed to be taken; information on major historic eruptions and recent activity; and evacuation procedures. An English version of the map is available in addition to the original in Japanese. This information is also available on the official tourism website of Kagoshima City (http://www. city.kagoshima.lg.jp/soumu/shichoshitu/kokusai/ en/emergency/sakurajima.html). Ballistics (called 'cinders') are additionally listed on the site as a possible volcanic hazard accompanied by a description, particle size and travel distance. To prepare for a future eruption from Sakurajima, Tarumizu City (Kagoshima Prefecture) runs an emergency response exercise every year (http:// www.city.tarumizu.lg.jp/kikikanri/kurashi/bosai/ bosai/taisaku/sakurajima.html).

Three other notable risk communication and mitigation measures have been implemented at Sakurajima. A Volcano Disaster Prevention Council was created as a means of communication to discuss disaster prevention measures between volcanologists, local government, JMA, and other invested agencies (http://www.data.jma.go.jp/svd/ vois/data/fukuoka/506_Sakurajima/506_bousai. html). Secondly, signs instructing people on the distance and direction to the nearest eruption safe house and evacuation port have been posted around the volcano. Lastly, concrete roofed shelters have been built around the island to protect visitors from falling ballistics (Erfurt-Cooper 2010).

\subsection{Eruption of Mt. Ontake, Japan}

Mt. Ontake is a stratovolcano located on the island of Honshu, Japan (Japan Meteorological Agency 2013a). It is not a continuously active volcano with four eruptions (all phreatic) in its historic record (1979, 1991, 2007 and 2014; Japan Meteorological Agency 2013a; Smithsonian Institution 2013).
Mt. Ontake straddles the boundary of two prefectures - Gifu and Nagano, with trails on either side. Both prefectures have developed hazard maps for two eruption scenarios that include ballistics - the first a phreatic eruption similar in size to the 1979 eruption (VEI 2) and the second a larger eruption on the scale of 90,000-20,000 year recurrence interval (Nagano hazard map: http://vivaweb2.bosai.go.jp/ v-hazard/L_read/53ontakesan/53ontake_2h03-L. pdf; Gifu hazard map: http://vivaweb2.bosai.go.jp/ v-hazard/L_read/53ontakesan/53ontake_2h01-L. pdf). In both maps, ballistic hazard is defined by a $4 \mathrm{~km}$ asymmetric zone around an asymmetric vent area encompassing the 1979 vents - the same vents that erupted in the 1991 and 2007 eruptions. The parameter by which the zone is based on is not provided (e.g. maximum travel distance, spatial density of impacts) and no advice accompanies the hazard map, though a residents' handbook was printed that included examples of what ballistics are and how far they can travel. The maps and handbooks are available on the NIED database and the prefectural government websites, though the map is not signposted around the volcano.

Mt. Ontake is constantly monitored by the JMA, with seismometers, GPS stations, tiltmeters, cameras and infrasonic microphones (Japan Meteorological Agency 2013a). In addition, preparedness communication measures also include Volcanic Alert Levels, in place since 2008 (Japan Meteorological Agency 2013a). Similarly to other volcanoes, these VALs range from 1 to 5 and include whether the alert level is a warning or forecast, the target area (e.g. crater area or more distal residential areas), the expected volcanic activity and phenomena with examples of previous cases, actions needed to be taken and also keywords accompanying the level (e.g. level 5 with 'evacuate').

The 27 September 2014 phreatic eruption occurred at lunchtime on a busy autumn day when $\sim 340$ hikers were on the mountain (Tsunematsu et al. 2016). Multiple pyroclastic surges were produced, travelling up to $2.5 \mathrm{~km}$ from vent, in addition to ballistics that impacted up to $1 \mathrm{~km}$ from the vent (Kaneko et al. 2016; 
Tsunematsu et al. 2016). Fifty-eight people were killed in the eruption, 55 most likely the result of ballistic trauma relatively close to the summit, with five still missing (as of 24 June 2016; Tsunematsu et al. 2016). An increase in summit seismicity was noted 16 days prior to the eruption resulting in the JMA releasing notices about volcanic activity, though activity was not at levels significant enough to raise the Volcanic Alert Level (there needed to be signs of deformation, which were not recorded until just prior to eruption; The Japan News, 26/10/14; Ui 2015). The eruption was largely unexpected with 11 min of precursory tremor, and uplift detected only seven minutes before the event (Ui 2015). This was a much shorter period of precursory activity than previous eruptions. The 1979 eruption was preceded by earthquake swarms for a year and five months. A month of seismicity was noted prior to the 1991 eruption, increasing in frequency just days before the event. And the 2007 eruption was preceded by inflation and seismicity for three months, accompanied by increasing fumarolic activity the week prior (Japan Meteorological Agency 2013a). Longer periods of precursory activity allow time for warnings to be issued. JMA released warnings prior to the 1991 and 2007 events, although the resulting eruptions were very small, only impacted the immediate area and occurred in winter outside the climbing season (Japan Meteorological Agency 2013a). However, if it had been possible to issue a warning when the precursory activity increased on the day of the 2014 eruption, it is unlikely that it would have resulted in no fatalities. Any evacuation warning prior to an event would need to occur at least an hour before the event and be immediately transmitted to all hikers on the summit area as it takes over an hour for hikers to move out of the ballistic hazard zone. Nonetheless, even a short warning time may have provided more hikers time to get to shelter.

Following the eruption, the Volcanic Alert Level was increased to 3, warning people not to approach the volcano (as access was restricted), and that blocks may be ejected up to $1 \mathrm{~km}$ from vent (based on previous eruptions). Signs were posted around the volcano telling people to "keep out" of the restricted area. Search and Rescue teams were deployed to rescue the injured hikers and those that sheltered in the buildings at the summit, and to recover the dead. Those that sheltered in the buildings around the summit survived the 2014 eruption, while many of the fatalities occurred due to hikers choosing to take photos and video of the eruption outside instead of running to the nearest hut. Half of the people autopsied by one doctor were found with cellphones in hand while one person's camera was found with a photo taken 4 min after the eruption occurred (Mainichi Shimbun 10/10/2014). Some then attempted to shelter around the summit shrine which they could not gain access to (the summit shrine is only open from the beginning of July to early September). Fatalities also occurred in exposed areas where there were no buildings in sight to shelter within. Personal safety measures taken by exposed hikers saved lives. This included sheltering behind large rocks, placing backpacks on heads, and wearing hard hats provided inside the mountain huts (NHK 2015).

Numerous risk management and communication tools have since been adopted. Prior to the eruption, Gifu and Nagano prefectures had separate commissions to manage volcanic activity from Mt. Ontake. Following the 2014 eruption they have combined to form one commission for the entire volcano, improving communication between the prefectures and subsequently to the public. The commission, similar to the Sakurajima council, is comprised of volcanologists, local government, JMA and other interested agencies (http://www.pref.nagano.lg.jp/kisochi/kisochi-sei saku/ontakesan/kazanbousaikyougikai.html). The council ran its first eruption evacuation drill on 4th June 2015.

Interviews conducted post-eruption showed that many climbers were unaware of the volcanic activity notices released, while of those that were aware $76 \%$ did not consider that they needed to be prepared for an eruption (The Japan News 
26/10/2014; Shinano Mainichi Shimbun 2015). JMA subsequently launched a website to provide climbers with its observations of the volcanic activity around Japan, in an attempt to improve communication to climbers. From the 1st April, 2015 the Gifu Prefectural Government made it mandatory for all climbers of Ontake to submit a mountain climbing notification form prior to ascending Mt. Ontake, in an effort to improve knowledge of the number and location of people on the mountain, and to improve communication in times of crisis by recording their emergency contact information (http://www.pref.gifu.lg.jp/ English/tourism/mountain/). Kiso, a town in the Nagano Prefecture responsible for one of the mountain trails, has also installed loudspeakers in the mountain cabins prior to easing restrictions in September 2015 (The Japan Times 27/09/2015).

In November 2015, a new hazard map was released by the Ontakesan Volcano Disaster Prevention Council (the combined commission mentioned previously). It provides two ballistic hazard zones - one for a phreatic eruption that extends $2 \mathrm{~km}$ from the vent area, and one for a larger magmatic eruption, extending $4 \mathrm{~km}$ from the vent area (http://www.city.gero.lg.jp/ hazardmap/\#12/35.9073/137.5203). The zones are based on research completed for Mt. Fuji on past ballistic distributions from phreatic and magmatic eruptions in Japan and around the world (Mount Fuji Disaster Prevention Council 2004). The asymmetric vent area has also been increased significantly, encompassing $3 \mathrm{~km}$ in length and $\sim 2 \mathrm{~km}$ in width. In addition, further research has been completed on the ballistic hazard produced in the eruption. Tsunematsu et al. (2016) describe an elongated distribution toward the N-NE resulting from an inclined ejection and topographic controls such as the shape of the valley the vents formed in. The spatial distribution was mapped from aerial photos by Kaneko et al. (2016) and delineated into four zones. The densest zone (A) encompasses areas with impact densities $>10$ impacts per $5 \times 5 \mathrm{~m}$, decreasing in density with distance from the vent to Zone $\mathrm{C}$ which has between 0 and 2 impacts per $5 \times 5 \mathrm{~m}$.

\section{Discussion}

\subsection{Understand the Context and Assess the Risk}

We identify from review of literature and analysis of the four case study volcanoes (Table 2) that understanding the risk context is highly important for effective communication associated with ballistic hazard and risk. Establishing this context and identifying potential risks requires engagement with potential stakeholders, such as those which may be exposed or affected by ballistic, or other, volcanic hazards. Effective communication is an essential component of this. Once these steps are complete, we then suggest that a ballistic risk assessment is undertaken to help underpin effective management and communication of ballistic hazard and risk. Best-practice ballistic risk assessment generally consists of: (1) reviewing the volcano's eruptive history to establish eruption frequency and eruption magnitude; (2) determining the nature and extent of past ballistic distributions; (3) exploring possible future ballistic distributions; (4) identifying assets exposed in the area; and (5) estimating the asset's vulnerability. Once complete, risk can be evaluated and appropriate management and communication strategies implemented. However, we stress that risk assessment alone cannot underpin effective communication of ballistic hazard and risk. But must be carried out in conjunction with the tools and strategies listed in Table 1 and Fig. 2.

It is important to remember that every context is different and what works at one volcano does not necessarily mean it will work or is needed at another. An assessment for a frequently erupting, highly visited volcano where risk management organisations are well resourced will require a different approach compared with an infrequently active, rarely visited volcano in a country where there are few resources available for risk management. The scope and scale of risk management activities should be guided by the risk context, and determine which and how risk management tools and strategies are used. 


\subsection{Reflections on the Four Case Study Volcanoes}

All of the volcanoes studied are capable of sustaining injuries and fatalities from ballistics. The Mt. Ontake 2014 eruption resulted in the most fatalities from any of the case studies, and provides a chance to analyse why this was so with the aim of preventing it from occurring again. Multiple factors contributed to the high fatality rate:

- The eruption happened in peak season when $\sim 340$ people were on the mountain.

- Precursory activity only increased $11 \mathrm{~min}$ prior to eruption, resulting in an unexpected eruption. This meant no warning was able to be issued to the people on the summit and no closure of the summit prior to the event occurred. Previous eruptions had precursory events that gave more warning of the impending eruption underscoring that past history should not be solely relied on to predict outcomes of future unrest.

- The Alert Level was not raised following increased seismicity beginning 16 days before the eruption. A requirement for this to occur is the presence of ground deformation, which was not recorded until $7 \mathrm{~min}$ before the eruption.

- Hikers chose to take images and video of the eruption instead of finding shelter. This decision may have been different had hazard maps been posted around the volcano with instructions on actions to take in an eruption.

Fatalities from ballistics could occur at all of the case study volcanoes. However, a scenario with fatalities on the scale seen at Ontake is unlikely from Sakurajima due to the $2 \mathrm{~km}$ restriction zone. Yasur is visited by much fewer tourists than Ontake so it is unlikely to see as many fatalities from one event as occurred at Ontake, although the lack of shelter, lack of hazard advice, and proximity to the vent means that ballistic casualties are still relatively likely at this volcano. Work is ongoing to reduce this risk. The August 2012 eruption of Upper Te Maari is the most comparable to the Ontake eruption as it was largely unheralded and of the same explosivity. If the August 2012 eruption had occurred in peak tourist season, then a similar amount of fatalities as Ontake potentially could have occurred.

\subsection{Critical Issues}

We identify the following critical issues for contemporary and future communication of volcanic ballistic risk, based on our review of literature and analysis of the four case study volcanoes. We note many of these issues transcend volcanic ballistics to include nearly all volcano types and volcanic hazards:

- What is the most effective way to manage and communicate risk from volcanoes which are (highly) visited and/or settled which experience eruptions with very short and/or no meaningful warnings (e.g. Ontake, Te Maari)? This is a critical issue for managing ballistic risk, as eruptions with longer unrest phases typically allow evacuation of ballistic hazard zones before the eruption.

- What are the most appropriate risk management and communication strategies for volcanoes where ballistic (and other) risk is present which have poorly understood eruptive histories and/or monitoring systems?

- Effective ballistic risk assessment requires greater understanding of (a) the distribution of ballistic from a range of potential eruption styles, (b) the impact of ballistics to people and other societal assets (vulnerability/fragility characteristics), and (c) identification and (crucially) evaluation of what are the most appropriate mitigation actions to reduce ballistic risks before, during and after an eruption.

- Successful management of ballistic risk requires effective engagement (of which communication is a keystone) between authorities responsible for managing risk at volcanoes, those people and organisations who may have economic, cultural and social connections with a volcano, and the scientific community who can help inform hazard and (sometimes) risk considerations. Organisational and governance frameworks to 
allow and facilitate this seem to be highly variable globally, but some relatively successful examples do exist (e.g. New Zealand).

- How to manage future risk, particularly for volcanoes where there is significant existing use and/or strong pressure to utilise the resources through tourism (increasing visitor numbers to high risk areas), and agricultural and settlement pressure from population growth.

\section{Conclusions}

Ballistic projectiles ejected in explosive eruptions present a major proximal hazard to life, infrastructure and the environment. An increasing population living on or close to active volcanoes and a growing volcano tourism industry give rise to an increased number of people exposed to ballistic hazard, presenting a considerable need for detailed ballistic hazard and risk assessments, and specialised communication and management strategies. Recommended strategies would include at least the following:

(1) Hazard and risk assessments (ideally probabilistic) specific to the volcano in question, which include ballistics where appropriate, that are made available to emergency managers and decision makers with authors/ scientists available to answer questions and advise where necessary and practical;

(2) The inclusion of ballistic hazard zones in hazard maps with accompanying advice on what to do. Maps should be updated in a crisis to reflect new information and readily available through a range of media. These maps should continue to be updated after the event when detailed scientific studies are complete;

(3) Volcano monitoring systems to monitor volcanic activity and indicate when a volcano is in unrest;

(4) The use of signage around the volcano to communicate ballistic hazard and risk, integrated with other hazard advice, including warning systems where practical, and with a focus on effectiveness of communication rather than just providing information;
(5) The use of volcanic alert bulletins, media releases or reports to communicate ballistic hazard and risk in crisis phases;

(6) Open, sufficiently frequent communication between scientists, stakeholders, emergency managers and local communities in which updates and training are provided, and informed input made into management and mitigation measures.

These strategies may vary with eruptive state (quiescence or crisis), frequency of eruptions, availability of resources, and whether ballistics are the main hazard at the particular volcano. In addition to the strategies mentioned in this chapter, further work is needed to test and update the advice provided to visitors on the actions to take in a ballistic eruption, in particular personal protective measures. Effort should also be made to provide consistent advice at all volcanoes on the actions to be taken, depending on the volcanic hazards involved. This way the information would be reinforced with visits to different volcanoes and increase the likelihood of visitors acting correctly.

Acknowledgements Funding for this study was provided by DeVoRA (Determining Volcanic Risk in Auckland) and a New Zealand Earthquake Commission (EQC) Biennial Grant (16/727). RHF is also supported by a doctoral scholarship from the Ngāi Tahu Research Centre. We wish to thank Bill McGuire and an anonymous reviewer for their thorough and constructive reviews.

\section{References}

Alatorre-Ibargüengoitia MA, Delgado-Granados H, Dingwell DB (2012) Hazard map for volcanic ballistic impacts at Popocatépetl volcano (Mexico). Bull Volc 74(9):2155-2169

Alatorre-Ibargüengoitia MA, Morales-Iglesias $\mathrm{H}$, Ramos-Hernández SG, Jon-Selvas J, Jiménez-Aguilar JM (2016) Hazard zoning for volcanic ballistic impacts at El Chichón Volcano (Mexico). Nat Hazards. doi:10.1007/s11069-016-2152-0

Artunduaga A, Jimenez G (1997) Third version of the hazard map of Galeras Volcano, Colombia. J Volcanol Geoth Res 77:89-100

Barclay J, Haynes K, Mitchell T, Solana C, Teeuw R, Darnell A, Crosweller HS, Cole P, Pyle D, Lowe C, Fearnley C, Kelman I (2008) Framing volcanic risk communication within disaster risk reduction: finding 
ways for the social and physical sciences to work together. Geol Soc, London, Spec Publ 305(1):163-177

Baxter P, Gresham A (1997) Deaths and injuries in the eruption of Galeras Volcano, Colombia, 14 January 1993. J Volcanol Geoth Res 77:325-338

Becker JS, Saunders WSA, Robertson CM, Leonard GS, Johnston DM (2010) A synthesis of challenges and opportunities for reducing volcanic risk through land use planning in New Zealand. Australas J Disaster Trauma Stud 2010:1

Bertolaso G, De Bernardinis B, Bosi V, Cardaci C, Ciolli S, Colozza R, Cristiani C, Mangione D, Ricciardi A, Rosi M, Scalzo A, Soddu P (2009) Civil protection preparedness and response to the 2007 eruptive crisis of Stromboli volcano, Italy. J Volcanol Geoth Res 182(3-4):269-277

Bird DK, Gisladottir G, Dominey-Howes D (2010) Volcanic risk and tourism in southern Iceland: implications for hazard, risk and emergency response education and training. J Volcanol Geoth Res 189:33-48

Blong RJ (1981) Some effects of tephra falls on buildings. In: Self S, Sparks RSJ (ed) Tephra studies, proceedings NATO Advanced Studies Institute, Laugarvatn and Reykjavik, 18-29 June 1980, pp 405-420

Blong RJ (1984) Volcanic hazards: a sourcebook on the effects of eruptions. Academic Press, Orlando

Blong RJ (1996) Volcanic hazards risk assessment. In: Scarpa R, Tilling RI (eds) Monitoring and mitigation of volcanic hazards. Springer, Berlin, pp 675-698

Booth B (1979) Assessing volcanic risk. J Geol Soc 136(3):331-340

Bower S, Woods A (1996) On the dispersal of clasts from volcanic craters during small explosive eruptions. J Volcanol Geoth Res 73:19-32

Breard ECP, Lube G, Cronin SJ, Fitzgerald R, Kennedy B, Scheu B, Montanaro C, White JDL, Tost M, Procter JN, Moebis A (2014) Using the spatial distribution and lithology of ballistic blocks to interpret eruption sequence and dynamics: August 6 2012 Upper Te Maari eruption, New Zealand. J Volcanol Geoth Res 286:373-386

Burby RJ, Wagner F (1996) Protecting tourists from death and injury in coastal storms. Disasters 20(1):49-60

Calvari S, Spampinato L, Lodato L (2006) The 5 April 2003 vulcanian paroxysmal explosion at Stromboli volcano (Italy) from field observations and thermal data. J Volcanol Geoth Res 149(1-2):160-175

Christiansen RL (1980) Eruption of Mount St. Helensvolcanology. Nature 285:531-533

Cole JW, Cowan HA, Webb TA (2006) The 2006 Raoul Island Eruption-a review of GNS science's actions. GNS Science Report 2006/7 38 p

Coombs ML, McGimsey RG, Browne BL (2008) Preliminary volcano-hazard assessment for Gareloi Volcano, Gareloi Island. Alaska Scientific Investigations Report 2008-5159

Cronin SJ, Sharp DS (2002) Environmental impacts on health from continuous volcanic activity at Yasur (Tanna) and Ambrym, Vanuatu. Int J Environ Health Res 12(2):109-123
Cronin SJ, Gaylord DR, Charley D, Alloway BV, Wallez S, Esau JW (2004) Participatory methods of incorporating scientific with traditional knowledge for volcanic hazard management on Ambae Island, Vanuatu. Bull Volcanol 66(7):652-668

Department of Conservation (2012) Volcanic risk in Tongariro National Park. http://www.doc.govt.nz/parksand-recreation/places-to-go/central-north-island/places/ tongariro-national-park/know-before-you-go/volcanicrisk-in-tongariro-national-park/. Accessed Mar 2015

Dohaney J, Brogt E, Kennedy B, Wilson TM, Lindsay JM (2015) Training in crisis communication and volcanic eruption forecasting: design and evaluation of an authentic role-play simulation. J Appl Volcanol 4:12

Drabek TE (1995) Disaster responses within the tourist industry. Int J Mass Emerg Disasters 13(1):7-23

Eissen JP, Blot C, Louat R (1991) Chronologie de l'activité volcanique historique de l'arc insulaire des Nouvelles-Hébrides de 1595 à 1991. Rapp. Scientifiques Technique, Sci. Terre Geol.-Geophys. - ORSTOM (Noumea) 2

Erfurt-Cooper P (2010) Volcano and geothermal tourism in Kyushu, Japan. Volcano and geothermal tourism: sustainable geo-resources for leisure and recreation, Earthscan, p. 142

Erfurt-Cooper P (2011) Geotourism in volcanic and geothermal environments: playing with fire? Geoheritage 3:187-193

Ewart JW, Harpel CJ (2004) In harm's way: Population and volcanic risk. Geotimes, American Geological Institute. http://www.geotimes.org/apr04/feature_VPI. html. Accessed 15 June 2016

Fagents S, Wilson L (1993) Explosive volcanic eruptions-VII. The ranges of pyroclasts ejected in transient volcanic explosions. Geophys J Int 113:359370

Fitzgerald RH, Tsunematsu K, Kennedy BM, Breard ECP, Lube G, Wilson TM, Jolly AD, Pawson J, Rosenberg MD, Cronin SJ (2014) The application of a calibrated 3D ballistic trajectory model to ballistic hazard assessments at Upper Te Maari, Tongariro. J Volcanol Geoth Res 286:248-262

Fudali R, Melson W (1972) Ejecta velocities, magma chamber pressure and kinetic energy associated with the 1968 eruption of Arenal volcano. Bull Volc 35:383-401

Geological Survey of Japan (2013) Sakurajima Volcano, 2nd edn. https://gbank.gsj.jp/volcano/Act_Vol/sakuraj ima/text/eng/exp01-5e.html. Accessed Feb 2015

GNS Science (2007) Volcanic hazards at Tongariro. http://info.geonet.org.nz/download/attachments/8585 571/Tongariro_Poster_A4.pdf. Accessed Mar 2015

GNS Science (2012) Te Maari Eruption Phenomena. http://info.geonet.org.nz/download/attachments/8585 571/Northern_Tongariro_eruption_phenomena.pdf. Accessed Mar 2015

Gregg CE, Houghton BF, Paton D, Swanson DA, Johnston DM (2004) Community preparedness for lava flows from Mauna Loa and Hualālai volcanoes, Kona, Hawai'i. Bull Volc 66:531-540 
Gurioli L, Harris AJL, Colo L, Bernard J, Favalli M, Ripepe M, Andronico D (2013) Classification, landing distribution, and associated flight parameters for a bomb field emplaced during a single major explosion at Stromboli, Italy. Geology 41(5):559-562

Hadisantono RD, Andreastuti MCHSD, Abdurachman EK, Sayudi DS, Nursusanto I, Martono A, Sumpena AD, Muzani M (2002) Peta Kawasan Rawan Bencana Gung Api Merapi, Jawa Tengah dan Daerah Istimewa Yogyakarta scale 1:50 000 Direktorat Vulkanologi dan Mitigasi Bencana Geologi, Bandung

Harris AJL, Ripepe M, Hughes EA (2012) Detailed analysis of particle launch velocities, size distributions and gas densities during normal explosions at Stromboli. J Volcanol Geoth Res 231-232:109-131

Haynes K, Barclay J, Pidgeon N (2007) Volcanic hazard communication using maps: an evaluation of their effectiveness. Bull Volc 70(2):123-138

Haynes K, Barclay J, Pidgeon N (2008) The issue of trust and its influence on risk communication during a volcanic crisis. Bull Volc 70(5):605-621

Houghton BF, Swanson DA, Carey RJ, Rausch J, Sutton AJ (2011) Pigeonholing pyroclasts: Insights from the 19 March 2008 explosive eruption of Kilauea volcano. Geology 39(3):263-266

Japan Meteorological Agency (2013a) 53 Ontakesan. National Catalogue of the active volcanoes in Japan (4th edn). http://www.data.jma.go.jp/svd/vois/data/ tokyo/STOCK/souran_eng/souran.htm\#kantotyubu. Accessed Nov 2014

Japan Meteorological Agency (2013b) 90 Sakurajima. National Catalogue of the active volcanoes in Japan (4th edn). http://www.data.jma.go.jp/svd/vois/data/ tokyo/STOCK/souran_eng/souran.htm\#kantotyubu. Accessed Nov 2014

Jenkins SF, Spence RJS, Fonseca JFBD, Solidum RU, Wilson TM (2014) Volcanic risk assessment: quantifying physical vulnerability in the built environment. J Volcanol Geoth Res 276:105-120

Johnston DM, Bebbington MS, Lai CD, Houghton BF, Paton D (1999) Volcanic hazard perceptions: comparative shifts in knowledge and risk. Disaster Prev Manag 8:118-126

Johnston DM, Houghton BF, Neall VE, Ronan KR, Paton D (2000) Impacts of the 1945 and 1995-1996 Ruapehu eruptions, New Zealand: an example of increasing societal vulnerability. Geol Soc Am Bull 112:720-726

Jolly AD, Jousset P, Lyons JJ, Carniel R, Fournier N, Fry B, Miller C (2014a) Seismo-acoustic evidence for an avalanche driven phreatic eruption through a beheaded hydrothermal system: An example from the 2012 Tongariro eruption. J Volcanol Geoth Res 286:331-347

Jolly GE, Keys HJR, Procter JN, Deligne NI (2014b) Overview of the co-ordinated risk-based approach to science and management response and recovery for the 2012 eruptions of Tongariro volcano, New Zealand. J Volcanol Geoth Res 286:184-207
Kagoshima City (2010) Sakurajima Volcano hazard map. http://www.city.kagoshima.lg.jp/soumu/shichos hitu/kokusai/en/emergency/documents/sakurazimahm_ eng.pdf. Accessed 19 Oct 2015

Kaneko T, Maeno F, Nakada S (2016) 2014 Mount Ontake eruption: characteristics of the phreatic eruption as inferred from aerial observations. Earth, Planets Space 68:72-82

Keys H (2015) Tongariro Alpine crossing visitors surveyed on effectiveness of new electronic light signs. Tongariro Aug 2015, pp 48-51. www.tongariro. org.nz/tongarirojournals. Accessed 18 Oct 2015

Keys HJR, Green PM (2010) Mitigation of volcanic risks at Mt Ruapehu, New Zealand. In: Malet J-P, Glade T, Casagli N (eds) Proceedings of the mountain risks international conference, Firenze, Italy, CERG, Strasbourg, France, 24-26 Nov 2010, pp. 485-490

Kilgour G, Della Pasqua F, Hodgson KA, Jolly GE (2010) The 25 September 2007 eruption of Mount Ruapehu, New Zealand: directed ballistics, surtseyan jets, and ice-slurry lahars. J Volcanol Geoth Res 191(1-2):1-14 Leonard GS, Johnston DM, Paton D, Christianson A, Becker J, Keys H (2008) Developing effective warning systems: ongoing research at Ruapehu volcano, New Zealand. J Volcanol Geoth Res 172(3-4):199-215

Leonard GS, Stewart C, Wilson TM, Procter JN, Scott BJ, Keys HJ, Jolly GE, Wardman JB, Cronin SJ, McBride SK (2014) Integrating multidisciplinary science, modelling and impact data into evolving, syn-event volcanic hazard mapping and communication: a case study from the 2012 Tongariro eruption crisis, New Zealand. J Volcanol Geoth Res 286:208-232

Lindell MK (2013) Risk perception and communication. In: Bobrowsky PT (ed) Encyclopedia of natural hazards. Springer, Netherlands, pp 870-874

Lube G, Breard ECP, Cronin SJ, Procter JN, Brenna M, Moebis A, Pardo N, Stewart RB, Jolly A, Fournier N (2014) Dynamics of surges generated by hydrothermal blasts during the 6 August 2012 Te Maari eruption, Mt. Tongariro, New Zealand. J Volcanol Geoth Res 286:348-366

Maeno F, Nakada S, Nagai M, Kozono T (2013) Ballistic ejecta and eruption condition of the vulcanian explosion of Shinmoedake volcano, Kyushu, Japan on 1 February, 2011. Earth, Planets Space 65(6):609-621

Mainichi Shimbun 10/10/2014. Ballistic blocks killed 20 people instantly. http://mainichi.jp/select/news/2014 1010k0000m040138000c.html. Accessed 29 June 2016

Mileti D, Nathe S, Gori P, Greene M, Lemersal E (2004) Public hazards communication and education: the state of the art. natural hazards informer, Issue 2 . Boulder, p. 13

Minakami T (1942) 5. On the distribution of volcanic ejecta (Part I.): the distributions of volcanic bombs ejected by the recent explosions of Asama. Bull Earthq Res Inst 20:65-92

Mount Fuji Disaster Prevention Council (2004) Report of Mount Fuji Hazard Map Examination Committee (in Japanese). http://www.bousai.go.jp/kazan/fujisankyougikai/report/. Accessed 28 Jun 2016 
Murphy PE, Bayley R (1989) Tourism and disaster planning. Geogr Rev 79(1):36-46

Nadim F (2013) Hazard. In: Bobrowsky PT (ed) Encyclopedia of natural hazards. Springer, Netherlands, pp 425-426

Nairn IA, Self S (1978) Explosive eruptions and pyroclastic avalanches from Ngauruhoe in February 1975. J Volcanol Geoth Res 3:36-60

Neal CA, McGimsey RG, Miller TP, Riehle JR, Waythomas CF (2001) Preliminary volcano-hazard assessment for Aniakchak Volcano, Alaska. United States Geological Survey Open File Report 00-519, Plate 1

NHK (Japan Broadcasting Corporation) (2015). Ontake: eyewitnesses or eruption. http://www.nhk.or.jp/d-navi/ link/ontake2014-en/index.html. Accessed Jul 212015

NIED (1980) Field report of the disaster from Ontake 1979 eruption. Natural Disaster Research Report 16, $41 \mathrm{p}$

Odbert H, Hincks T, Aspinall W (2015) Combining volcano monitoring timeseries analysis with Bayesian Belief Networks to update hazard forecast estimates. EGU General Assembly 2015, 12-17 Apr 2015, Vienna, Austria

Oikawa T, Yoshimoto M, Nakada S, Maeno F, Komori J, Shimano T, Takeshita Y, Ishizuka Y, Ishimine Y (2016) Reconstruction of the 2014 eruption sequence of Ontake Volcano from recorded images and interviews. Earth, Planets Space 68:79

Pardo N, Cronin SJ, Németh K, Brenna M, Schipper CI, Breard E, White JDL, Procter J, Stewart B, Agustin-Flores J, Moebis A, Zernack A, Kereszturi G, Lube G, Auer A, Wallace C (2014) Perils in distinguishing phreatic from phreatomagmatic ash; insights into the eruption mechanisms of the 6 August 2012 Mt. Tongariro eruption, New Zealand. J Volcanol Geoth Res 286:397-414

Paton D, Millar M, Johnston DM (2001) Community resilience to volcanic hazard consequences. Nat Hazards 24:157-169

Paton D, Smith L, Daly M, Johnston D (2008) Risk perception and volcanic hazard mitigation: individual and social perspectives. J Volcanol Geoth Res 172(34):179-188

Pistolesi M, Rosi M, Pioli L, Renzulli A, Bertagnini A, Andronico D (2008) The paroxysmal event and its deposits. The Stromboli Volcano: an integrated study of the 2002-2003 eruption. Geophysica, 317-330

Pomonis A, Spence R, Baxter P (1999) Risk assessment of residential buildings for an eruption of Furnas Volcano, Sao Miguel, the Azores. J Volcanol Geotherm Res 92(1-2):107-131

Robertson R, Cole P, Sparks RSJ, Harford C, Lejeune AM, McGuire WJ, Miller AD, Murphy MD, Norton G, Stevens NF, Young SR (1998) The explosive eruption of Soufriere Hills Volcano, Montserrat, West Indies, 17 September, 1996. Geophys Res Lett 25(18):3429-3432

Scott BJ, Potter SH (2014) Aspects of historical eruptive activity and volcanic unrest at Mt. Tongariro, New Zealand: 1846-2013. J Volcanol Geoth Res 286:263-276

Shinano Mainichi Shimbun (2015) Verification of Mount Ontake eruption-living with a volcano. What do we learn from 9.27? The Shinano Mainichi Shimbun Press, Nagano (in Japanese)

Siegrist M, Cvetkovich G (2000) Perception of hazards: the role of social trust and knowledge. Risk Anal 20 (5):713-720

Sigurdsson H, Lopes-Gautier R (1999) Volcanoes and tourism. In: Sigurdsson H, Houghton B, McNutt SR, Rymer H, Stix J (eds) Encyclopedia of volcanoes. Academic Press, Cambridge, pp 1283-1299

Slovic P (2000) Perception of risk. In: Slovic P (ed) The perception of risk. Earthscan, London, pp 220-231

Small C, Naumann T (2001) The global distribution of human population and recent volcanism. Environ Hazards 3:93-109

Smithsonian Institution (2013) Ontakesan bulletin reports, Global Volcanism Program. http://www.volcano.si. edu/volcano.cfm?vn=283040. Accessed Dec 2014

Sorensen JH (2000) Hazard warning systems: review of 20 years of progress. Nat Hazards Rev 1(2):119-125

Sorensen JH (2013) Communicating emergency information. In: Bobrowsky PT (ed) Encyclopedia of natural hazards. Springer, Netherlands, pp 110-112

Sparks RSJ, Aspinall WP, Crosweller HS, Hincks TK (2013) Risk and uncertainty assessment of volcanic hazards. In: Sparks RJS, Hill L (eds) Risk and uncertainty assessment for natural hazards. Cambridge University Press, Cambridge

Steinberg G, Lorenz V (1983) External ballistic of volcanic explosions. Bull Volcanol 46(4):333-348

Swanson DA, Zolkos SP, Haravitch B (2012) Ballistic blocks around Kîlauea Caldera: Their vent locations and number of eruptions in the late 18th century. J Volcanol Geoth Res 231-232:1-11

The Japan News 26/10/2014. Improved steps needed to inform volcano climbers in Japan. http://the-japan-news. com/news/article/0001671312. Accessed 28 Oct 2014

The Japan News 27/10/2014. Mt. Ontake risks reported in 1979. http://the-japan-news.com/news/article/000167 3442. Accessed 28 Oct 2014

The Japan Times 27/9/2015. Families of Ontake victims mark first anniversary of deadly eruption. http://www. japantimes.co.jp/news/2015/09/27/national/familieson takevictimsmarkfirstanniversarydeadlyeruption/\#.VxR fHDB942w. Accessed 18 Apr 2016

Thompson MA, Lindsay JM, Gaillard JC (2015) The influence of probabilistic volcanic hazard map properties on hazard communication. J Appl Volcanol 4:6

Thouret J-C, Lavigne F, Kelfoun K, Bronto S (2000) Toward a revised hazard assessment at Merapi volcano, Central Java. J Volcanol Geoth Res 100(1-4): 479-502

Tsunematsu K, Ishimine Y, Kaneko T, Yoshimoto M, Fujii T, Yamaoka K (2016) Estimation of ballistic block landing energy during 2014 Mount Ontake eruption. Earth, Planets Space 68:88

Turtle EP, Lopes RMC, Lorenz RD, Radebaugh J, Howell RR (2016) Temporal behavior and temperatures of Yasur volcano, Vanuatu from field remote sensing observations, May 2014. J Volcanol Geoth Res. doi:10.1016/j.jvolgeores.2016.02.030 
Twigg J (2002) The human factor in early warnings: risk perception and appropriate communications. In: Zschau J, Kuppers AN (eds) Early warning systems for natural disaster reduction. Springer, Berlin, pp 19-26

Ui T (2015) The difficulty of predicting volcanic eruptions and releasing information. Geography 60(5):43-49 (In Japanese)

UNISDR (2009) United Nations International Strategy for Disaster Risk Reduction: UNISDR Terminology on Disaster Risk Reduction (2009). http://www.unisdr. org/eng/terminology/terminology-2009-eng.html. Accessed Jun 2015

Vanuatu Geohazards Observatory (2009) Volcanic Alert Status. http://www.geohazards.gov.vu/index.php/hazardsupdated-events/volcano-alert-status. Accessed Mar 2015

Vanuatu Geohazards Observatory (2014) Vanuatu Monitoring Network (2012-2014). http://www.geohazards. gov.vu/index.php/geophysical-monitoring-network/ vanuatu-monitoring-network. Accessed Apr 2015

Wardman J, Sword-Daniels V, Stewart C, Wilson T (2012) Impact assessment of the May 2010 eruption of
Pacaya volcano, Guatemala. GNS Science Report 2012/09, $90 \mathrm{p}$

Williams KL, Keys HJR (2013) Reducing volcanic risk on the Tongariro Alpine Crossing. Report of a workshop 24 September 2013. Department of Conservation Tongariro District, $36 \mathrm{p}$

Wilson L (1972) Explosive volcanic eruptions II. The atmospheric trajectories of pyroclasts. Geophys J Roy Astron Soc 30(1):381-392

Wilson TM, Stewart C, Wardman JB, Wilson G, Johnston DM, Hill D, Hampton SJ, Villemure M, McBride S, Leonard G, Daly M, Deligne N, Roberts L (2014) Volcanic ashfall preparedness poster series: a collaborative process for reducing the vulnerability of critical infrastructure. J Appl Volcanol 3:10

Yamagishi H, Feebrey C (1994) Ballistic ejecta from the 1988-1989 andesitic Vulcanian eruptions of Tokachidake volcano, Japan: morphological features and genesis. J Volcanol Geoth Res 59(4):269-278
Open Access This chapter is distributed under the terms of the Creative Commons Attribution 4.0 International License (http://creativecommons.org/licenses/by/4.0/), which permits use, duplication, adaptation, distribution and reproduction in any medium or format, as long as you give appropriate credit to the original author(s) and the source, provide a link to the Creative Commons license and indicate if changes were made.
The images or other third party material in this chapter are included in the work's Creative Commons license, unless indicated otherwise in the credit line; if such material is not included in the work's Creative Commons license and the respective action is not permitted by statutory regulation, users will need to obtain permission from the license holder to duplicate, adapt or reproduce the material. 